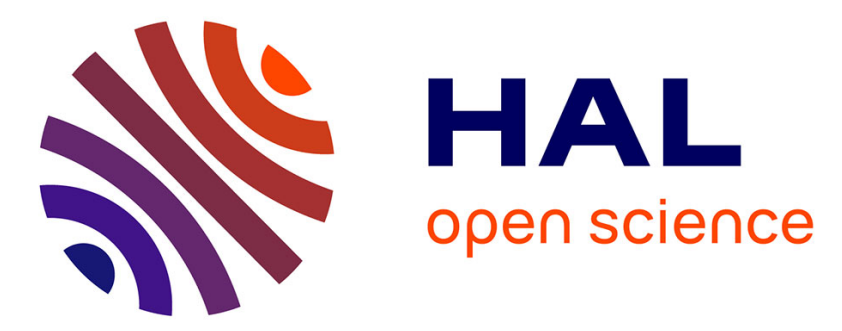

\title{
Hydrolysis properties, corrosion behavior and microhardness of AZ91 "model" alloys
}

Serge Al Bacha, Isabelle Aubert, Mirvat Zakhour, Michel Nakhl, Jean-Louis Bobet

\section{> To cite this version:}

Serge Al Bacha, Isabelle Aubert, Mirvat Zakhour, Michel Nakhl, Jean-Louis Bobet. Hydrolysis properties, corrosion behavior and microhardness of AZ91 "model" alloys. Journal of Alloys and Compounds, 2020, 845, 156283 (10 p.). 10.1016/j.jallcom.2020.156283 . hal-02946035

\section{HAL Id: hal-02946035 \\ https://hal.science/hal-02946035}

Submitted on 23 Sep 2020

HAL is a multi-disciplinary open access archive for the deposit and dissemination of scientific research documents, whether they are published or not. The documents may come from teaching and research institutions in France or abroad, or from public or private research centers.
L'archive ouverte pluridisciplinaire HAL, est destinée au dépôt et à la diffusion de documents scientifiques de niveau recherche, publiés ou non, émanant des établissements d'enseignement et de recherche français ou étrangers, des laboratoires publics ou privés. 


\title{
Hydrolysis properties, corrosion behavior and microhardness of AZ91 "model" alloys
}

S. Al Bacha ${ }^{\mathrm{a}, \mathrm{b}}$, I. Aubert ${ }^{\mathrm{c}}$, M. Zakhour ${ }^{\mathrm{a}}$, M. Nakhl ${ }^{\text {a }}$, J.-L. Bobet ${ }^{\mathrm{b} *}$.

${ }^{a}$ LCPM/PR 2 N (EDST), Lebanese University, Faculty of Sciences II, 90656 Jdeidet El Metn, Lebanon.

${ }^{\mathrm{b}}$ University of Bordeaux, ICMCB, UMR 5026, F-33600 Pessac, France.

${ }^{c}$ University of Bordeaux, CNRS, Arts et Metiers Institute of technology, Bordeaux INP, INRAE, I2M Bordeaux, F-33400 Talence, France.

\begin{abstract}
A model AZ91 alloy containing the same amount of $\mathrm{Mg}$ and $\mathrm{Mg}_{17} \mathrm{Al}_{12}$ than a commercial AZ91 alloy was reproduced using various strategies. These "model" materials consist of a "homemade AZ91" powder, $\mathrm{Mg}$ melted or milled with $\mathrm{Mg}_{17} \mathrm{Al}_{12}$. The properties of the various model materials were compared to the commercial alloy (used as reference). The weak bond between $\mathrm{Mg}$ and $\mathrm{Mg}_{17} \mathrm{Al}_{12}$ is highlighted by SEM observations. Milling $\mathrm{Mg}$ with $\mathrm{Mg}_{17} \mathrm{Al}_{12}$ enhances the formation of microstructural defects due to the brittleness of the intermetallic. Vickers microhardness of pure $\mathrm{Mg}_{17} \mathrm{Al}_{12}$ is $250 \mathrm{Hv}$ while that of $\mathrm{AZ91}$ is $72 \mathrm{Hv}$. The hardness of $\mathrm{Mg}_{17} \mathrm{Al}_{12}$ decreases gradually from the center of the particle to its border in contact with $\mathrm{Mg}$ while the hardness of $\mathrm{Mg}$ is higher at the interface $M g-M_{17} A_{12}$. The galvanic coupling between $M g$ and $\operatorname{Mg}_{17} \mathrm{Al}_{12}$ improves the hydrolysis performance of the materials. The best hydrolysis performance was $80 \%$ of the theoretical capacity of hydrogen production reached in 60 minutes by the milled $\mathrm{Mg}+\mathrm{Mg}_{17} \mathrm{Al}_{12}$. The preparation method of the models strongly affects their corrosion behavior. The passivation layer formed during the corrosion of highly-reactive materials affects the electrochemical measurements results. The mechanical properties and the corrosion behavior of the model materials depends on their composition and their structure.
\end{abstract}

Keywords: $\mathrm{AZ91}, \mathrm{Mg}-\mathrm{Al}$ alloys, $\mathrm{Mg}_{17} \mathrm{Al}_{12}$, hydrogen, hardness, corrosion.

* corresponding author: jean-louis.bobet @icmcb.cnrs.fr (J.-L. Bobet) 


\section{Introduction}

Corrosion is considered among the main challenges to widen the usage of materials. It is defined as the destruction of the material by a chemical and/or electrochemical reaction with its environment [1]. The degradation is usually accompanied by a loss of the useful properties of the material. Based on the interaction between the material and its environment, the corrosion may be localized or uniform. Localized corrosion reactions are more frequent than uniform corrosion reactions and include: pitting corrosion (studied a lot in chloride solution), crevice corrosion, filiform corrosion, galvanic corrosion, stress corrosion cracking, intergranular corrosion and corrosion fatigue [2]. In this work, we will be focusing on galvanic corrosion since it affects the most the corrosion mechanism of the alloys, which is described as the interaction between different species (e.g. metals) in the presence of an electrolyte and an electron conductive path [2,3]. The electron flow caused by the potential difference favors the oxidation of the more negative potential metal (becomes the anode) while it lowers the corrosion of the more positive potential metal (becomes the cathode) [1]. Many factors affect galvanic corrosion such as the size of the anode and the cathode, the conditions of the aqueous media (i.e. composition, temperature, $\mathrm{pH}, \ldots$ ), the potential difference and most significantly the surface ratio between the anode and the cathode. From these factors, it is clear that galvanic corrosion occurs at the microstructure scale in multiphase materials as in magnesium-based materials. In these alloys, magnesium $(\mathrm{Mg})$ acts as anode $\left(\mathrm{E}_{\mathrm{corr}}=-1.65 \mathrm{~V} / \mathrm{SCE}[4]\right)$ while second phases (owing higher open circuit potentials) act as cathodes.

Among all Mg alloys, AZ91 is one of the most popular commercial alloy due to its good mechanical and corrosion resistance properties [5,6]. The microstructure of AZ91 alloys consists of a primary $\alpha$ phase (i.e. $\mathrm{Mg}$ rich), a second $\beta$-phase (i.e. $\mathrm{Mg}_{17} \mathrm{Al}_{12}$ ), a binary solid solution $\mathrm{Mg}_{0.97} \mathrm{Zn}_{0.03}$ and $\mathrm{Al}_{\mathrm{x}} \mathrm{Mn}_{\mathrm{y}}$ phases [7-17] depending on the solidification and the processing route [18, 19]. In AZ91, $\mathrm{Mg}_{17} \mathrm{Al}_{12}$, with an open circuit potential of -1.2 V/SCE [20, 21], acts as a cathode. As the surface ratio between the anode and the cathode influences the galvanic corrosion, the role of $\mathrm{Mg}_{17} \mathrm{Al}_{12}$ in the corrosion process of $\mathrm{AZ91}$ alloys was evaluated by changing its distribution and morphology in the $\mathrm{Mg}$ matrix [5, 19, 22, 23]. It was found that, depending on the surface ratio of $\mathrm{Mg}_{17} \mathrm{Al}_{12}$ and $\mathrm{Mg}, \beta$-phase may act as a corrosion barrier or a galvanic cathode $[9,10,14,24$ 26]. However, the corrosion behavior of pure $\mathrm{Mg}_{17} \mathrm{Al}_{12}$ investigation [27] clarified its role in the 
corrosion of $\mathrm{AZ}$ alloys where the barrier effect was explained by the lower corrosion kinetics compared to $\mathrm{Mg}\left(\mathrm{J}_{\text {corr }}\left(\mathrm{Mg}_{17} \mathrm{Al}_{12}\right)=5.3 \mu \mathrm{A} / \mathrm{cm}^{2}\right.$ [27] vs. $\left.\mathrm{J}_{\text {corr }}(\mathrm{Mg})=558 \mu \mathrm{A} / \mathrm{cm}^{2}[4]\right)$.

Most of the previous studies tended to investigate the corrosion behavior of AZ91 alloys in order to enhance their corrosion resistance. However, the corrosion of Mg-based materials may have some benefits. The oxidation of $\mathrm{Mg}$ (during its corrosion) is accompanied by the reduction of water from the aqueous media to produce hydrogen gas $\left(\mathrm{H}_{2}\right)$. This reaction is usually reported as the hydrolysis reaction of $\mathrm{Mg}$ or $\mathrm{Mg}$-based materials [28-30]. For instance, the hydrolysis reactivity of a material is the same as its anodic dissolution without taking into consideration the negative difference effect (NDE) [31, 32].

Hydrogen production by the hydrolysis/corrosion of AZ91 alloy appears to be an ideal solution for low-cost hydrogen production and for the waste management of Mg-based scrap [7, 33-36]. The reactivity of $\mathrm{AZ91}$ and $\mathrm{Mg}_{17} \mathrm{Al}_{12}$ was improved by ball milling with cheap additives such as graphite and aluminum chloride [7, 20, 27, 33, 34]. However, the interaction between pure Mg and pure $\mathrm{Mg}_{17} \mathrm{Al}_{12}$ in the same material is not clear yet. In fact, previous studies explained this interaction based on the variation of their morphology and their distribution.

Besides, the effect of $\mathrm{Mg}_{17} \mathrm{Al}_{12}$ on the mechanical properties of $\mathrm{Mg}$ - $\mathrm{Al}$ alloys was also investigated [37-40]. Chowdary et al. [38] attributed the highest measured Vickers micro-hardness value, measured on AZ91 sample, to $\mathrm{Mg}_{17} \mathrm{Al}_{12}(133.5 \mathrm{Hv})$ and the lowest one to $\mathrm{Mg}(86.3 \mathrm{Hv})$. When heat treatment was applied on AZ91 alloy, the distribution of $\mathrm{Mg}_{17} \mathrm{Al}_{12}$ in $\mathrm{Mg}$ becomes more homogeneous and as consequence the overall hardness of the alloy was improved [38-40]. The influence of $\mathrm{Mg}_{17} \mathrm{Al}_{12}$ on the hardness of $\mathrm{Mg}-\mathrm{Al}$ alloys was highlighted by Sunil et al. [37] when comparing the Vickers microhardness of AZ31 and AZ91. In fact, the presence of the brittle $\mathrm{Mg}_{17} \mathrm{Al}_{12}$ increases the hardness of AZ91 to an average of $110 \mathrm{Hv}$ vs. an average of $85 \mathrm{Hv}$ for $\mathrm{AZ31}$ (note that $\mathrm{AZ31}$ does not contain $\mathrm{Mg}_{17} \mathrm{Al}_{12}, C f$ reference [37]).

This work attempts to elucidate the effect of $\mathrm{Mg}_{17} \mathrm{Al}_{12}$ on the corrosion behavior and the hardness of AZ91 alloys. The contribution of the ultra-minority phases $\mathrm{Mg}_{0.97} \mathrm{Zn}_{0.03}$ and $\mathrm{Al}_{\mathrm{x}} \mathrm{Mn}_{\mathrm{y}}$ is not considered throughout this study. In an attempt to simulate the contact between $\mathrm{Mg}$ and $\mathrm{Mg}_{17} \mathrm{Al}_{12}$ in AZ91 alloys, three "model" materials and a reference were compared to a commercial AZ91 alloy. The reference consists of a Mg-Al-Zn powder mixture (90:9:1 in wt.\%) while the "model" 
materials are a homemade AZ91 powder (Mg powder melted with $\mathrm{Al}$ and $\mathrm{Zn}$ powders, 90:9:1 in wt.\%) and a mixture of pure $\mathrm{Mg}$ and pure $\mathrm{Mg}_{17} \mathrm{Al}_{12}$ synthesized by co-fusion and by ball milling. The results will clarify the role of $\mathrm{Mg}_{17} \mathrm{Al}_{12}$ during the hydrolysis/corrosion of $\mathrm{Mg}-\mathrm{Al}$ alloys offering better understanding on how the hydrolysis of these alloys could be improved. Corrosion behavior (i.e. hydrogen production) investigated by anodic polarization, electrochemical impedance spectroscopy and hydrolysis tests will be discussed in terms of microstructural (XRD) and morphological (SEM-EDS, Laser granulometry and Vickers microhardness) analysis.

\section{Experimental details}

\subsection{Models preparation}

Magnesium powder (Strem Chemicals, 99.8\%), aluminum powder (Strem Chemicals, 99.7\%) and Zinc powder (Prolabo, 99.5\%) were used as starting material. "Mg-Al-Zn" was prepared by mixing 90 wt.\% of $\mathrm{Mg}, 9$ wt.\% of $\mathrm{Al}$ and $1 \mathrm{wt} . \%$ of $\mathrm{Zn}$ in ultrasonic homogenizer in acetone. The mixture was placed into a stainless-steel container and dried for $48 \mathrm{~h}$ at $373 \mathrm{~K}$ under Ar atmosphere to get fully rid of air contamination. The same mixture (i.e. Mg-Al-Zn) was heated following the temperature program adopted for the synthesis of pure $\mathrm{Mg}_{17} \mathrm{Al}_{12}$ [27] to obtain a homemade AZ91 powder (subsequently named AZ91 powder). AZ91 alloy was provided from a local supplier in Bordeaux, France. In order to study the influence of $\mathrm{Mg}_{17} \mathrm{Al}_{12}$ on the corrosion behavior of $\mathrm{Mg}$, 78 wt.\% of $\mathrm{Mg}$ and 21 wt.\% of pre-synthesized $\mathrm{Mg}_{17} \mathrm{Al}_{12}$ (i.e. 90 wt.\% of $\mathrm{Mg}$ and 10 wt.\% of Al) mixtures were synthesized following two procedures: (i) the mixtures was heated at $813 \mathrm{~K}$ following the temperature program of the synthesis of pure $\mathrm{Mg}_{17} \mathrm{Al}_{12}$ [27], hence this material will be named " $\mathrm{Mg}+\mathrm{Mg}_{17} \mathrm{Al}_{12}$ fusion" and (ii) the mixture was ball milled under Ar for $1 \mathrm{~h}$ with a rotational speed of $250 \mathrm{rpm}$ following the milling procedure reported previously [7, 27], hence this material will be named " $\mathrm{Mg}+\mathrm{Mg}_{17} \mathrm{Al}_{12}$ milling". 


\subsection{Materials characterization}

The samples were analyzed by X-ray diffraction (XRD) using a Philips PANalyticalX'Pert

(PW1820) diffractometer with $\mathrm{Cu} \mathrm{K \alpha 1}$ radiation $(\lambda=1.5405 \AA)$ for structural characterization and crystalline phases identification. From the XRD refinement using EVA software, Mg crystallite size $\left(\tau_{\mathrm{Mg}}\right)$ and $\mathrm{Mg}_{17} \mathrm{Al}_{12}$ crystallite size $\left(\tau_{\mathrm{Mg} 17 \mathrm{Al1} 2}\right)$ were estimated according to the weighted Scherrer formula. Morphology was observed by scanning electron microscopy (SEM) using a TESCAN VEGA3 SB microscope equipped with a secondary electron detector (SE), a backscattered electron detector (BSE) and an energy dispersive X-ray spectrometer (EDS) for the elemental surface composition analysis. Particle size distribution was evaluated by laser granulometry in absolute ethanol using a MASTERSIZER2000 from Malvern® and results $\left(\mathrm{d}_{90}\right.$; i.e. $90 \%$ of the particles have a diameter smaller than the represented $\mathrm{d}_{90}$ ) are expressed as number distribution. The Vickers microhardness was measured using a Leica VMHT Auto testing instrument equipped with a pyramidal diamond indenter. An indent force of $1 \mathrm{~N}$ was applied for $10 \mathrm{~s}$ on the polished surfaces. The microhardness (Hv) for each sample was estimated using the equation 6.2.6 reported in reference [41]. Average hardness of a minimum of 10 indentations at different regions of the samples is estimated.

\subsection{Hydrogen production and electrochemical measurements}

The hydrolysis performances of the materials were evaluated by monitoring the volume of hydrogen produced over time in a $3.5 \mathrm{wt} . \% \mathrm{NaCl}$ solution (i.e. similar to seawater) $[7,27,28,34$, 42]. Hydrogen production is presented as the conversion yield (\%), which is defined as the volume of produced hydrogen over the theoretical volume of hydrogen calculated using the hydrolysis equation of pure $\mathrm{Mg}$ [43] and pure $\mathrm{Mg}_{17} \mathrm{Al}_{12}$ [27].

Mg-Al-Zn, $\mathrm{Mg}+\mathrm{Mg}_{17} \mathrm{Al}_{12}$ fusion and $\mathrm{Mg}+\mathrm{Mg}_{17} \mathrm{Al}_{12}$ milling were cold-pressed by applying a load of $5500 \mathrm{~kg} / \mathrm{cm}^{2}$ for $3 \mathrm{~min}$ to obtain dense pellets with an exposed surface of $0.8 \mathrm{~cm}^{2}$. Whereas, AZ91 powder was hot-pressed at $200^{\circ} \mathrm{C}$ for 30 minutes while applying a load of $500 \mathrm{~kg} / \mathrm{cm}^{2}$ due to the weak bond between $\mathrm{Mg}$ and $\mathrm{Mg}_{17} \mathrm{Al}_{12}$ [44]. A sample of $0.8 \mathrm{~cm}^{2}$ was cut from the AZ91 
alloy in order to investigate its corrosion behavior and microhardness. All samples were embedded in an insulating resin before electrochemical tests.

Electrochemical measurements (e.g. Open Circuit Potential (OCP), anodic polarization curve and Electrochemical Impedance Spectroscopy (EIS)) were performed using an electrochemical workstation (Ametek VersaSTAT 3F type) at room temperature in $3.5 \mathrm{wt} \% \mathrm{NaCl}$ solution with a classical three-electrode cell setup [4, 7, 20, 21]. Titanium mesh was used as the counter electrode. All given potentials refer to the saturated calomel electrode (SCE) used as the reference electrode. Before each test, pellets were wet ground with ethanol to a 4000-grit finish. After immersion in $\mathrm{NaCl}$ solution for 30 minutes while measuring the OCP, anodic polarization tests were performed by switching the potential to $-50 \mathrm{mV} / \mathrm{OCP}$ and scanned up to $+250 \mathrm{mV} / \mathrm{OCP}$ at a scan rate of 0.5 $\mathrm{mV} / \mathrm{s}$. The EIS measurements were carried out over a frequency ranging from $100 \mathrm{kHz}$ to 700 $\mathrm{mHz}$ with a $10 \mathrm{mV}$ amplitude sinusoidal voltage at OCP after 30 minutes of immersion in the solution. The EIS results were fitted using the commercial ZView 3.5f software. All above electrochemical measurements were repeated at least twice for better reproducibility. The results obtained from the best fit are reported in the present manuscript.

Note that structural analysis, morphological analysis and hydrolysis tests were performed on powders while electrochemical measurements and Vickers hardness tests were achieved on pellets. For AZ91 alloy, hydrolysis tests were made using pellets obtained by face-milling [7].

\section{Results and discussion}

\subsection{AZ91 models characterization}

Figure 1 shows the XRD patterns of $\mathrm{Mg}-\mathrm{Al}-\mathrm{Zn}, \mathrm{AZ91}$ powder, $\mathrm{AZ91}$ alloy, $\mathrm{Mg}+\mathrm{Mg}_{17} \mathrm{Al}_{12}$ fusion and $\mathrm{Mg}+\mathrm{Mg}_{17} \mathrm{Al}_{12}$ milling. The $\mathrm{Mg}_{17} \mathrm{Al}_{12}$ phase is not observed in $\mathrm{Mg}-\mathrm{Al}-\mathrm{Zn}$ powder since the heating temperature is lower than that needed to form the intermetallic $(750 \mathrm{~K})[27,45]$. However, the other materials are principally composed of approximately $78 \mathrm{wt} \%$ of $\mathrm{Mg}$ and $20 \mathrm{wt} \%$ of $\mathrm{Mg}_{17} \mathrm{Al}_{12}$ with a minor presence of $\mathrm{MgO}$ (2 wt.\%). 


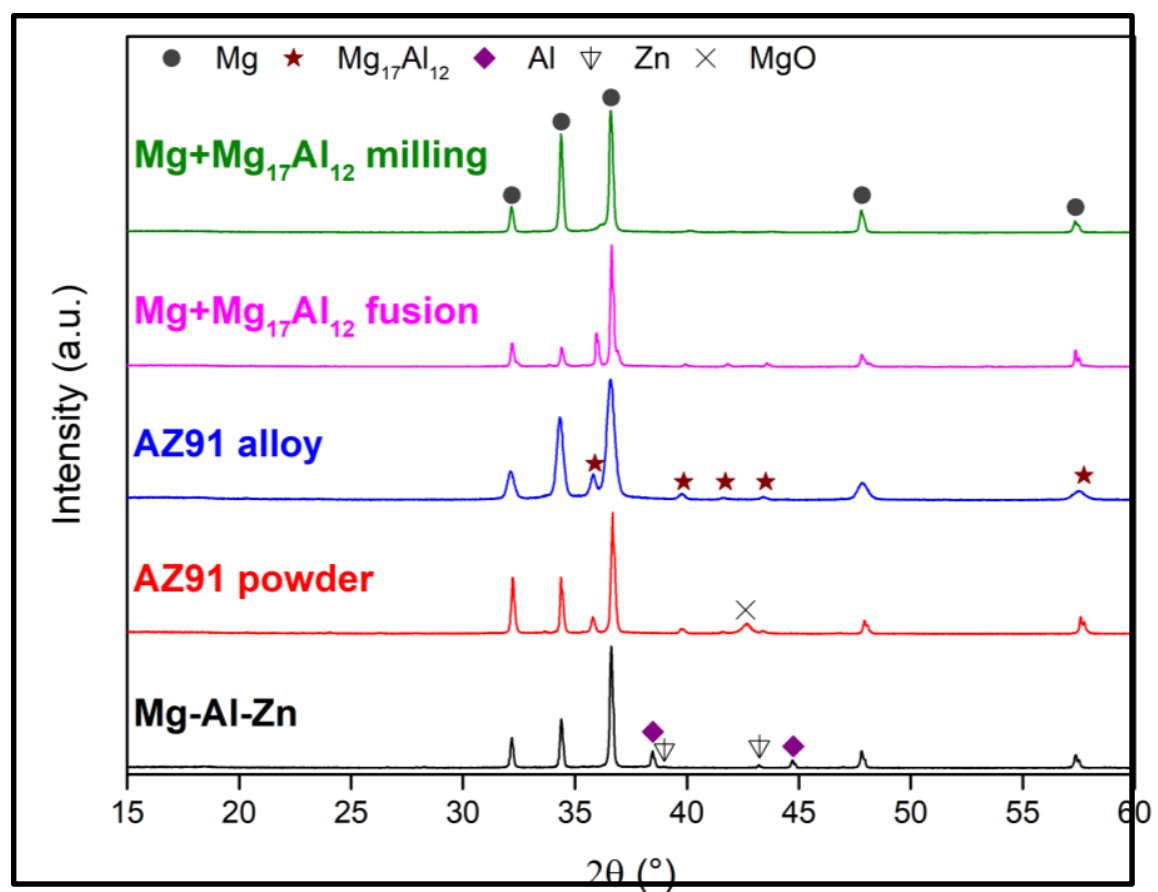

Figure 1: XRD patterns of $\mathrm{Mg}-\mathrm{Al}-\mathrm{Zn}$, AZ91 powder, $\mathrm{AZ91}$ alloy, $\mathrm{Mg}+\mathrm{Mg}_{17} \mathrm{Al}_{12}$ fusion and $\mathrm{Mg}+\mathrm{Mg}_{17} \mathrm{Al}_{12}$ milling.

In an earlier investigation [7], the presence of $\mathrm{Mg}_{0.97} \mathrm{Zn}_{0.03}$ in the same $\mathrm{AZ91}$ alloy was highlighted. In the present work, the contribution of this $\mathrm{MgZn}$ solid solution in the mechanical properties, the corrosion behavior and the hydrogen generation is considered identical to that of pure $\mathrm{Mg}$. The broadening of the X-ray diffraction peaks is attributed to crystallite size reduction. $\mathrm{Mg}$ crystallite size $\left(\tau_{\mathrm{Mg}}\right)$ decreases from $86 \mathrm{~nm}$ for $\mathrm{Mg}-\mathrm{Al}-\mathrm{Zn}$ to an average of $65 \mathrm{~nm}$ for the model materials and it shows a minimum of $25 \mathrm{~nm}$ for AZ91 alloy (Table 1). The commercial alloy was manufactured at low temperature, which does not favor the growth of $\mathrm{Mg}$ crystals. $\mathrm{Mg}_{17} \mathrm{Al}_{12}$ crystallite size $\left(\tau_{\mathrm{Mg} 17 \mathrm{Al12}}\right)$ shows the highest value $(83 \mathrm{~nm})$ for $\mathrm{Mg}+\mathrm{Mg}_{17} \mathrm{Al}_{12}$ fusion where the pure $\mathrm{Mg}_{17} \mathrm{Al}_{12}$ was co-fusioned with pure $\mathrm{Mg}$ without any further treatment (Table 1). $\tau_{\mathrm{Mg} 17 \mathrm{Al12}}$ is approximately the same for AZ91 powder and AZ91 alloy (i.e. $\tau_{\mathrm{Mg} 17 \mathrm{Al12}}=32 \mathrm{~nm}, C f$ Table 1) and decreases to a minimum of $8 \mathrm{~nm}$ for $\mathrm{Mg}+\mathrm{Mg}_{17} \mathrm{Al}_{12}$ milling as previously reported [27]. 
Table 1: $\mathrm{Mg}$ crystallite size $\left(\tau_{\mathrm{Mg}}\right), \mathrm{Mg}_{17} \mathrm{Al}_{12}$ crystallite size $\left(\tau_{\mathrm{Mg} 17 \mathrm{Al1}}\right)$, particle size $\mathrm{d}_{90}$ and Vickers microhardness (HV0.1) of all the materials involved in this study.

\begin{tabular}{|l|c|c|c|c|}
\hline \multicolumn{1}{|c|}{ Sample } & $\boldsymbol{\tau}_{\mathbf{M g}}(\mathbf{n m})$ & $\boldsymbol{\tau}_{\text {Mg17Al12 }}(\mathbf{n m})$ & Particle size d90 $(\boldsymbol{\mu m})$ & HV0.1 \\
\hline $\mathrm{Mg}-\mathrm{Al}-\mathrm{Zn}$ & 86 & - & 54 & $47 \pm 2$ \\
\hline $\mathrm{AZ91}$ powder & 65 & 32 & 18 & $110 \pm 8$ \\
\hline $\mathrm{AZ91}$ alloy & 25 & 34 & Flakes & $72 \pm 2$ \\
\hline $\mathrm{Mg}+\mathrm{Mg}_{17} \mathrm{Al}_{12}$ fusion & 65 & 83 & 33 & $110 \pm 67$ \\
\hline $\mathrm{Mg}+\mathrm{Mg}_{17} \mathrm{Al}_{12}$ milling & 69 & $8^{*}$ & 28 & $66 \pm 10$ \\
\hline
\end{tabular}

$*$ the uncertainty on this value is significant but it is indicative that the size of crystallites is very small.

AZ91 powder shows the lowest particle size distribution with a d90 of $18 \mu \mathrm{m}$ (Table 1). During the synthesis of this $\mathrm{AZ} 91$ homemade powder, the intermetallic $\mathrm{Mg}_{17} \mathrm{Al}_{12}$ is formed and detached from $\mathrm{Mg}$ due to the weak bond between them [44]. This explains the low particle size and the fact that AZ91 powder could not be densified by cold-pressing. On the other hand, $\mathrm{d}_{90}$ for $\mathrm{Mg}+\mathrm{Mg}_{17} \mathrm{Al}_{12}$ milling is lower than that of $\mathrm{Mg}+\mathrm{Mg}_{17} \mathrm{Al}_{12}$ fusion (i.e. $28 \mu \mathrm{m}$ vs. $33 \mu \mathrm{m}$ ) due to the presence of brittle $\mathrm{Mg}_{17} \mathrm{Al}_{12}$ [37] during ball milling of $\mathrm{Mg}$ which favors particle size reduction.

SEM images (figure 2) were captured via two detectors (i.e. BSE and SE) in order to get information about (i) the chemical composition (elucidate the presence of $\mathrm{Mg}$ and $\mathrm{Mg}_{17} \mathrm{Al}_{12}$ ) with BSE and (ii) surface morphology (by SE). 

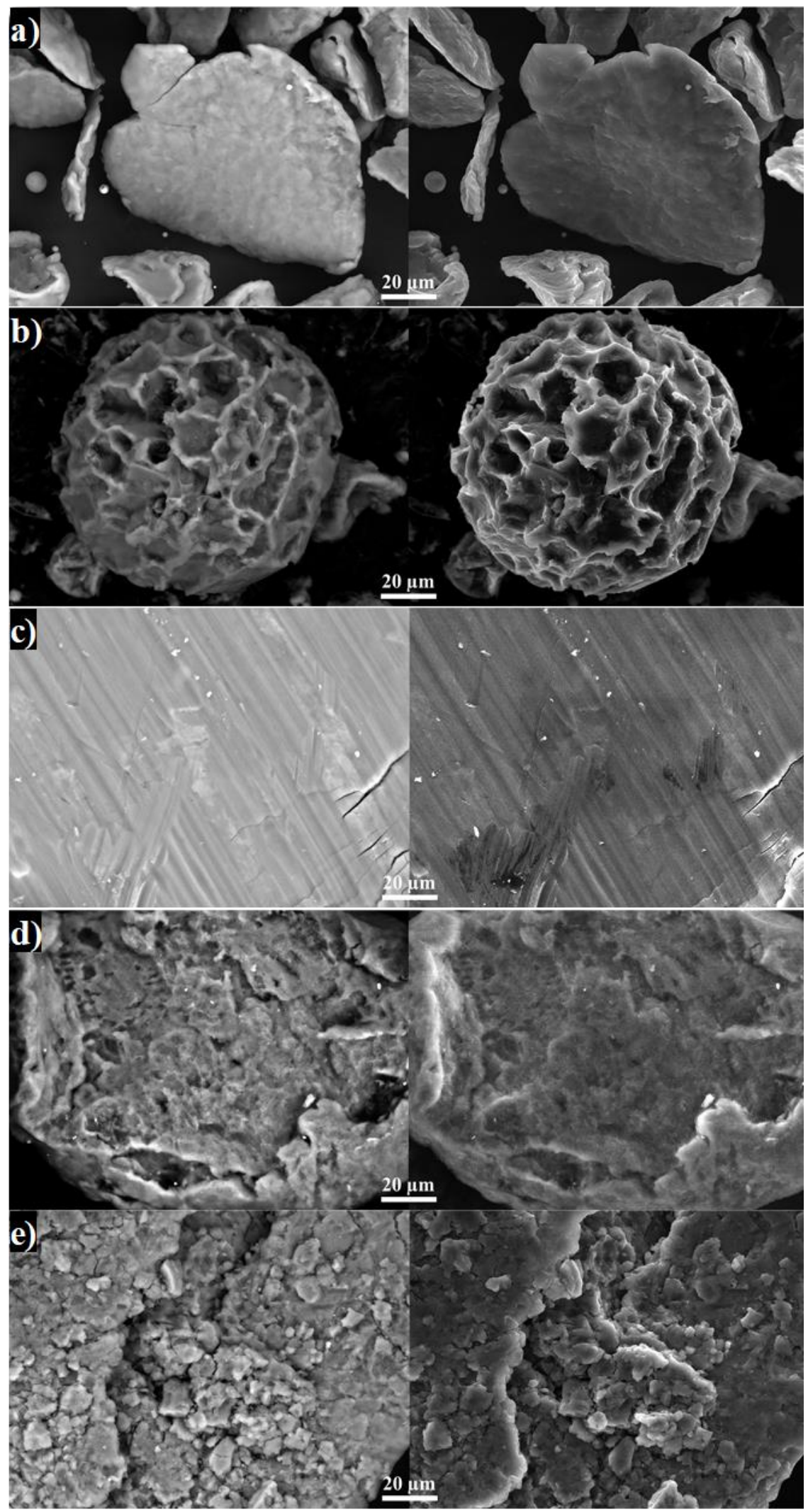

Figure 2: BSE (left) and SE (right) images of a) Mg-Al-Zn, b) AZ91 powder, c) AZ91 alloy, d) $\mathrm{Mg}+\mathrm{Mg}_{17} \mathrm{Al}_{12}$ fusion and e) $\mathrm{Mg}+\mathrm{Mg}_{17} \mathrm{Al}_{12}$ milling. 
Mg-Al-Zn powders are flat and relatively homogeneous (figure 2.a) whereas AZ91 powder shows particles with a porous structure (figure 2.b). It is possible to attribute this structure to the weak bond between $\mathrm{Mg}$ and $\mathrm{Mg}_{17} \mathrm{Al}_{12}$ [44] where the formed intermetallic detaches from $\mathrm{Mg}$ leaving empty spaces as Raney Nickel (pores of $10 \mu \mathrm{m}$ ). Figure 2.c reveals the presence of $\mathrm{Mg}_{17} \mathrm{Al}_{12}$ (white stains) and $\mathrm{Mg}$. When $\mathrm{Mg}_{17} \mathrm{Al}_{12}$ is heated with $\mathrm{Mg}$, small fibers type are observed on the surface of $\mathrm{Mg}+\mathrm{Mg}_{17} \mathrm{Al}_{12}$ fusion (figure 2.d) while $\mathrm{Mg}+\mathrm{Mg}_{17} \mathrm{Al}_{12}$ shows a rough surface with surface defects (figure 2.e).

Figure 3 highlights the distribution of $\mathrm{Mg}$ and $\mathrm{Al}$ atoms on the surface of $\mathrm{Mg}+\mathrm{Mg}_{17} \mathrm{Al}_{12}$ milling where surface defects were formed as shown also in figure 2.e. On overlay of $\mathrm{Mg}$ and $\mathrm{Al}$ distribution is presented in figure 3 to highlight the presence of $\mathrm{Mg}_{17} \mathrm{Al}_{12}$ on the surface of $\mathrm{Mg}$. It is shown that $\mathrm{Mg}_{17} \mathrm{Al}_{12}$ forms small particles on the surface and the reduction of $\mathrm{Mg}_{17} \mathrm{Al}_{12}$ particle size is accompanied by the formation of microstructural defects (i.e. cracks).

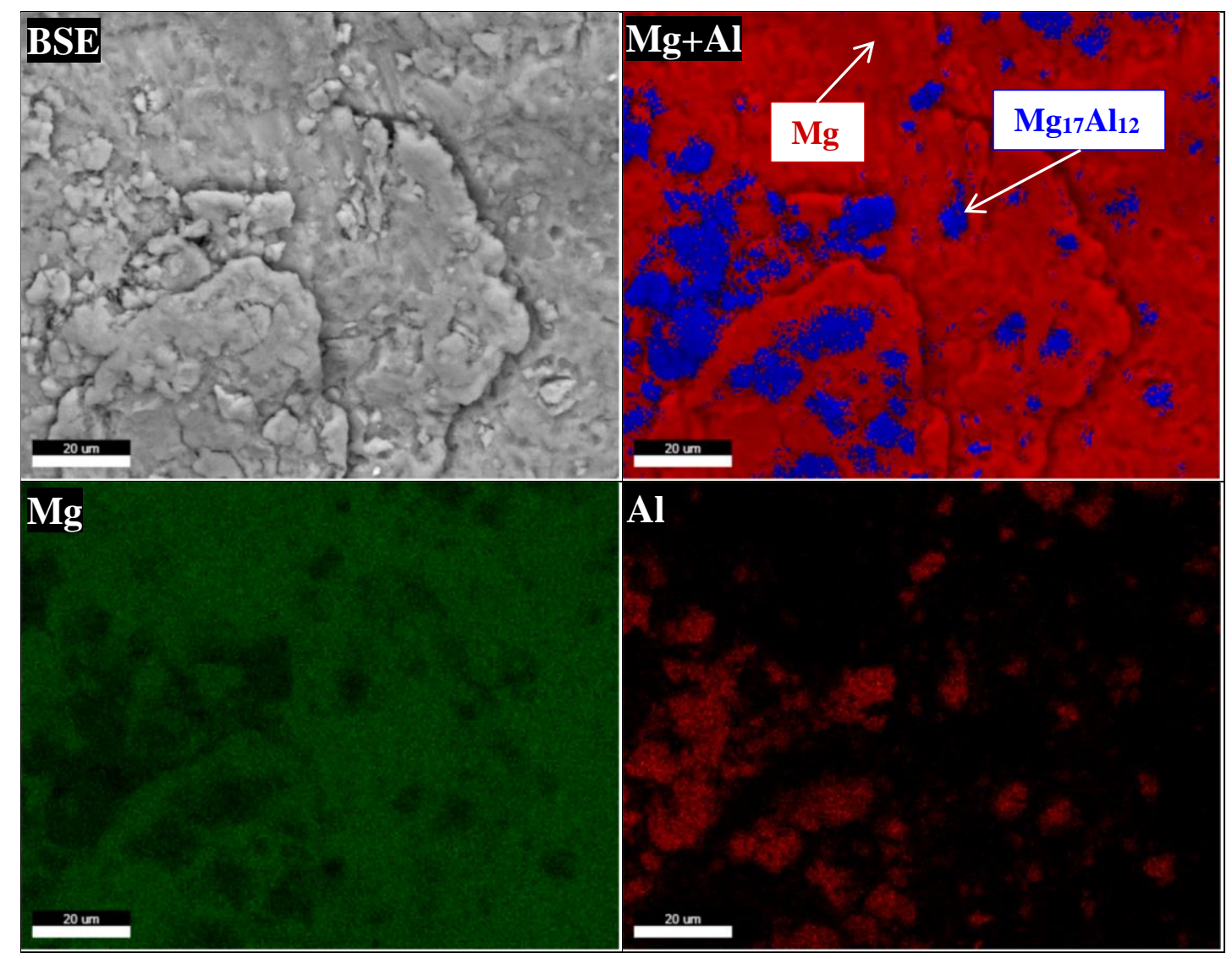

Figure 3: BSE image and EDS mapping of $\mathrm{Mg}+\mathrm{Mg}_{17} \mathrm{Al}_{12}$ milling. 
In order to better understand this microstructure, Vickers microhardness of pure $\mathrm{Mg}_{17} \mathrm{Al}_{12}$ was evaluated. Furthermore, the mechanical properties of the models were compared to the commercial alloy.

\subsection{Vickers hardness}

The resistance of a material to a deformation can be quantified by the Vickers microhardness (Hv). The average hardness of pure $\mathrm{Mg}_{17} \mathrm{Al}_{12}$ is $250 \pm 5 \mathrm{Hv}$ while that of $\mathrm{Mg}$ is $45 \pm 2 \mathrm{Hv}$ [46, 47]. The hardness of pure $\mathrm{Mg}_{17} \mathrm{Al}_{12}$ is higher than that of $\mathrm{Mg}_{17} \mathrm{Al}_{12}$ in $\mathrm{AZ91}$ alloy reported by Chowdary et al. (i.e. $133.5 \mathrm{Hv}, C f$ reference [38]). Table 1 (last left column) shows the mean Vickers hardness for $\mathrm{Mg}-\mathrm{Al}-\mathrm{Zn}, \mathrm{AZ91}$ powder, $\mathrm{AZ91}$ alloys and $\mathrm{Mg}+\mathrm{Mg}_{17} \mathrm{Al}_{12}$ materials. The reference powder (i.e. $\mathrm{Mg}-\mathrm{Al}-\mathrm{Zn}$ ) has, as expected, approximately the same hardness as $\mathrm{Mg}$ (47 $\pm 2 \mathrm{Hv}, C f$ Table 1) since no intermetallic compound is formed. The microhardness of $\mathrm{Mg}+\mathrm{Mg}_{17} \mathrm{Al}_{12}$ milling is relatively equivalent to that of AZ91 alloy (72 Hv). But the hardness of this alloy is lower than that reported previously and this is probably due to the repartition of $\mathrm{Mg}_{17} \mathrm{Al}_{12}$ in the $\mathrm{Mg}$ matrix (suggesting that the hardness is expressed only by the rule of mixture [46]). The higher hardness values (i.e. 110 $\mathrm{Hv}$ ) measured for $\mathrm{AZ91}$ powder and $\mathrm{Mg}+\mathrm{Mg}_{17} \mathrm{Al}_{12}$ fusion indicates an extensive contribution of $\mathrm{Mg}_{17} \mathrm{Al}_{12}$ in the mechanical properties of the material. Higher measurement uncertainty is indicative of material heterogeneity especially for $\mathrm{Mg}+\mathrm{Mg}_{17} \mathrm{Al}_{12}$ fusion.

In order to investigate the mechanical properties of $\mathrm{Mg}$ and $\mathrm{Mg}_{17} \mathrm{Al}_{12}$ in a "model" $\mathrm{AZ91}$, microhardness indents were carried out by linear scanning on the surface of $\mathrm{Mg}+\mathrm{Mg}_{17} \mathrm{Al}_{12}$ fusion (Figure 4). The indenter was placed on $\mathrm{Mg}$ surface, on $\mathrm{Mg}_{17} \mathrm{Al}_{12}$ surface and on a surface containing $\mathrm{Mg}$ and $\mathrm{Mg}_{17} \mathrm{Al}_{12}\left(\mathrm{Mg}, \mathrm{Mg}_{17} \mathrm{Al}_{12}\right.$ and $\mathrm{Mg}-\mathrm{Mg}_{17} \mathrm{Al}_{12}$ in the legend of Figure 4 respectively). 


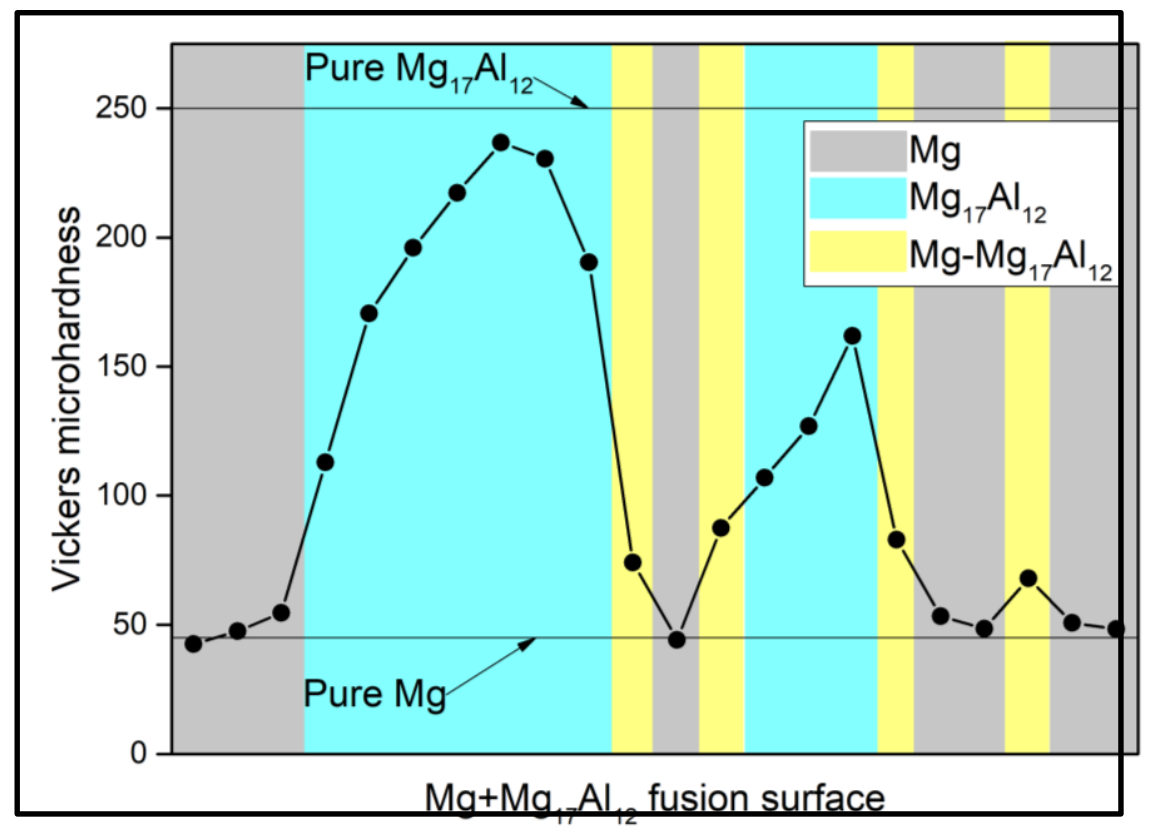

Figure 4: Vickers micro-hardness variation on $\mathrm{Mg}+\mathrm{Mg}_{17} \mathrm{Al}_{12}$ fusion surface.

Figure 4 shows that the hardness of $\mathrm{Mg}$ slightly increases at the interface between $\mathrm{Mg}$ and $\mathrm{Mg}_{17} \mathrm{Al}_{12}$. For $\mathrm{Mg}_{17} \mathrm{Al}_{12}$, the hardness increases gradually from the border (the interface between $\mathrm{Mg}$ and $\mathrm{Mg}_{17} \mathrm{Al}_{12}$ ) to the center of the grain. This is a typical composite effect where the weak bond between $\mathrm{Mg}$ and $\mathrm{Mg}_{17} \mathrm{Al}_{12}$ decreases the hardness of $\mathrm{Mg}_{17} \mathrm{Al}_{12}$ in contact with $\mathrm{Mg}$. Based on our results, the lowest value of $\mathrm{Mg}_{17} \mathrm{Al}_{12}$ hardness (133.5 Hv [38]) can be explained by the small size of its particles. In other word, the measured hardness was not that of pure $\mathrm{Mg}_{17} \mathrm{Al}_{12}$ but was influenced by the $\mathrm{Mg}$ matrix. The higher hardness values of $\mathrm{Mg}-\mathrm{Mg}_{17} \mathrm{Al}_{12}$ materials (compared to pure $\mathrm{Mg}$ ) offer new perspectives for giving a "second life" as ball milling additive. In fact, milling Mg with AZ91 alloys will induce the formation of surface defects which acts as the initiator sites for the hydrolysis reaction in the presence of $\mathrm{Cl}^{-}$ions $[2,48]$. 


\subsection{Hydrogen production by the hydrolysis reaction}

Hydrolysis test of powder were performed in a model seawater solution (i.e. 3.5 wt.\% of $\mathrm{NaCl}$ ) using powders. Figure 5 shows that the reactivity, in term of hydrogen generation, varies as follow: $\mathrm{Mg}+\mathrm{Mg}_{17} \mathrm{Al}_{12}$ milling $>\mathrm{AZ91}$ powder $>\mathrm{Mg}+\mathrm{Mg}_{17} \mathrm{Al}_{12}$ fusion $>\mathrm{Mg}-\mathrm{Al}-\mathrm{Zn}>\mathrm{AZ91}$ alloy .

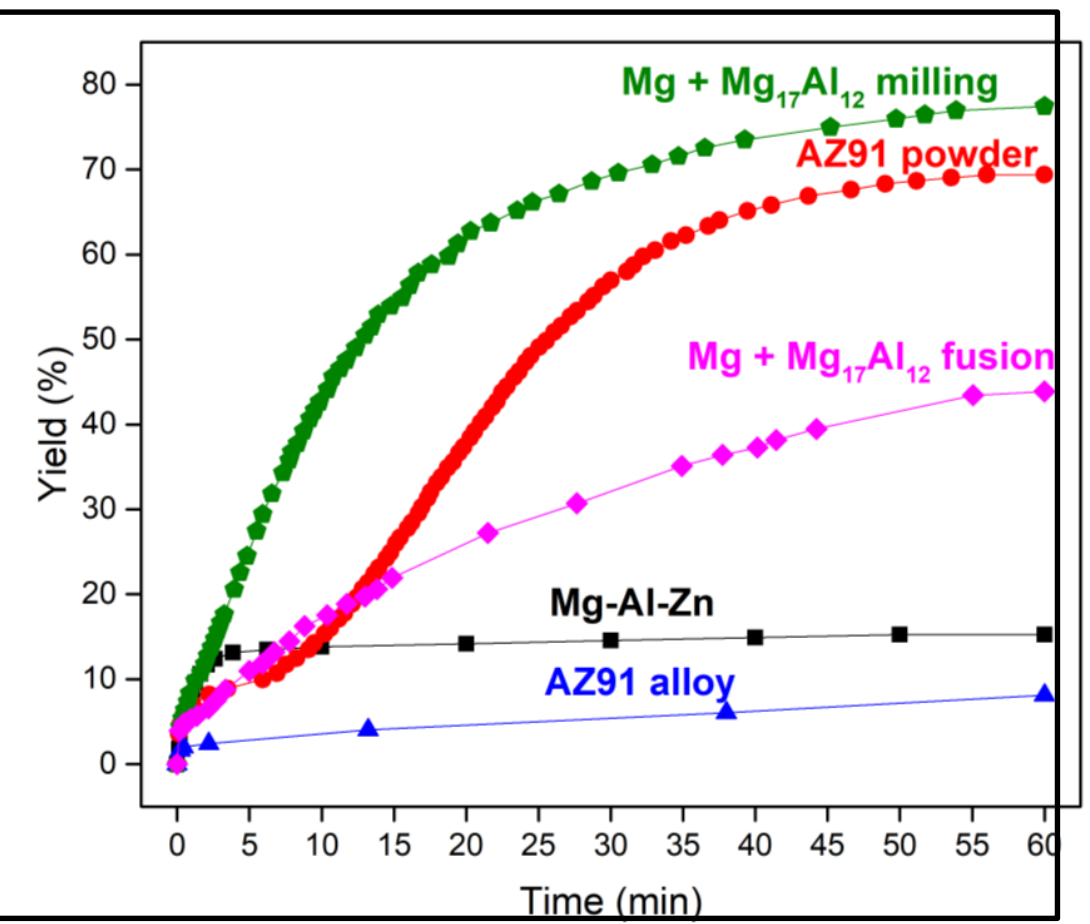

Figure 5: Hydrogen generation of $\mathrm{Mg}-\mathrm{Al}-\mathrm{Zn}$, $\mathrm{AZ91}$ powder, $\mathrm{AZ91}$ alloy, $\mathrm{Mg}+\mathrm{Mg}_{17} \mathrm{Al}_{12}$ fusion and $\mathrm{Mg}+\mathrm{Mg}_{17} \mathrm{Al}_{12}$ milling.

The highest hydrolysis performance (i.e. both yield and kinetics) of $\mathrm{Mg}+\mathrm{Mg}_{17} \mathrm{Al}_{12}$ milling is justified by the establishment of micro-galvanic cells between $\mathrm{Mg}$ and $\mathrm{Mg}_{17} \mathrm{Al}_{12}$ (as reported between $\mathrm{Mg}$ and $\mathrm{Ni}[28,30,48])$ and the presence of microstructural defects which enhances the pitting corrosion in the presence of $\mathrm{Cl}^{-}$ions $[2,28,48]$. Note that the hydrolysis reaction of AZ91 powder occurs in 2 steps: in the first step (during the first 5 minutes), only $\mathrm{Mg}$ reacts with the electrolyte to form $\mathrm{Mg}(\mathrm{OH})_{2}$ while in the second step (from 5 minutes till the end of the reaction) a magnesium-aluminum hydroxide is formed indicating the contribution of $\mathrm{Mg}_{17} \mathrm{Al}_{12}$ in the hydrogen production process. The pellets of AZ91 alloy barely react with a production of $10 \%$ of 
their theoretical hydrogen production capacity in 60 minutes. The relative low surface area of the pellets does not favor the dissolution of the passivation film of $\mathrm{Mg}(\mathrm{OH})_{2}$ formed during the hydrolysis (this phenomenon is well described by the Noyes-Whitney equation [49]).

In order to highlight the effect of $\mathrm{Mg}_{17} \mathrm{Al}_{12}$ on the hydrolysis performance of $\mathrm{Mg}$, the reactivity of $\mathrm{Mg}+\mathrm{Mg}_{17} \mathrm{Al}_{12}$ fusion was compared to that of pure $\mathrm{Mg}$ and pure $\mathrm{Mg}_{17} \mathrm{Al}_{12}$ while the performance of $\mathrm{Mg}+\mathrm{Mg}_{17} \mathrm{Al}_{12}$ milling was compared to milled $\mathrm{Mg}$ and milled $\mathrm{Mg}_{17} \mathrm{Al}_{12}$ (with the same milling conditions). These results are shown in Figures 6.a and 6.b respectively.

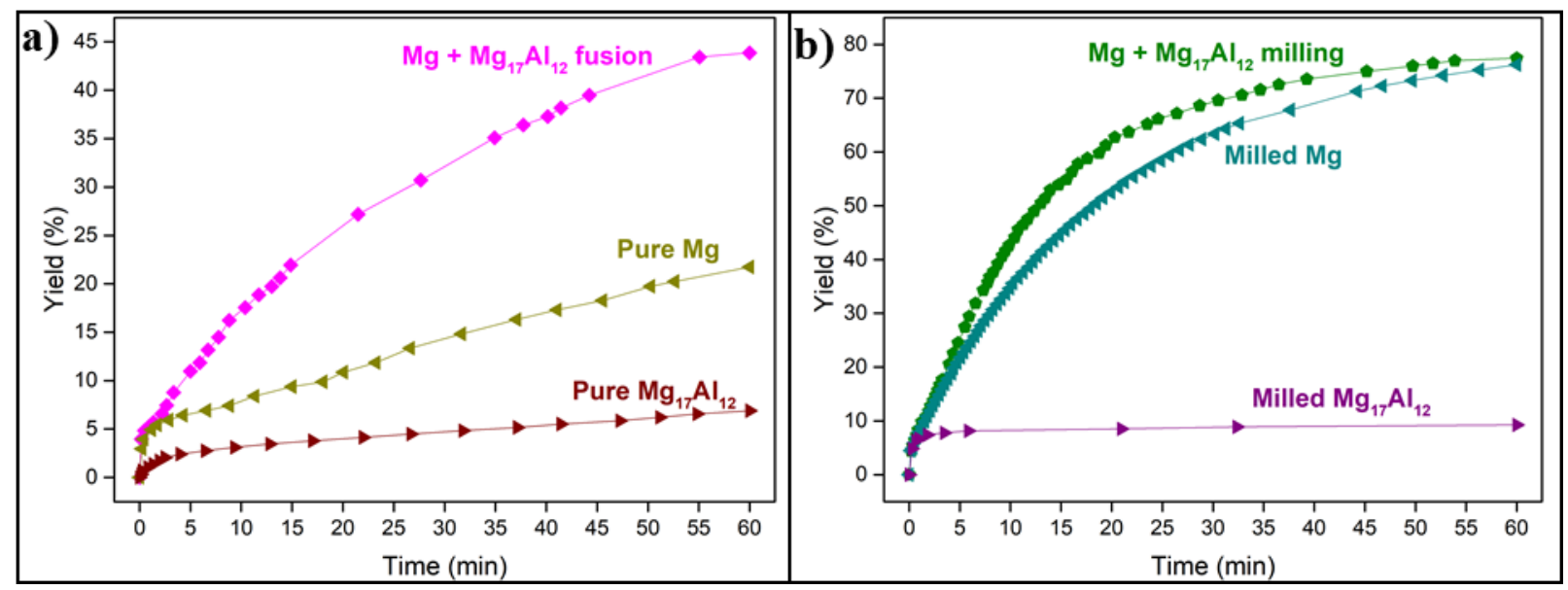

Figure 6: Hydrogen generation of a) pure $\mathrm{Mg}$, pure $\mathrm{Mg}_{17} \mathrm{Al}_{12}$ and $\mathrm{Mg}+\mathrm{Mg}_{17} \mathrm{Al}_{12}$ fusion and b) milled $\mathrm{Mg}$, milled $\mathrm{Mg}_{17} \mathrm{Al}_{12}$ and $\mathrm{Mg}+\mathrm{Mg}_{17} \mathrm{Al}_{12}$ milling.

Pure $\mathrm{Mg}_{17} \mathrm{Al}_{12}$ barely reacts with $\mathrm{NaCl}$ solution with a generation of $6 \%$ of its theoretical $\mathrm{H}_{2}$ production capacity in 60 minutes whereas pure $\mathrm{Mg}$ produces $20 \%$ in the same duration. Conversely, the hydrolysis performances of $\mathrm{Mg}+\mathrm{Mg}_{17} \mathrm{Al}_{12}$ fusion are better than that of the pure materials with a yield of $43 \%$ reached in 60 minutes of reaction. Note that the theoretical hydrogen production capacity by the hydrolysis of $\mathrm{Mg}+\mathrm{Mg}_{17} \mathrm{Al}_{12}$ materials was calculated by considering the hydrogen production from both $\mathrm{Mg}$ and $\mathrm{Mg}_{17} \mathrm{Al}_{12}$. Henceforth, the enhancement in the hydrolysis reactivity of $\mathrm{Mg}+\mathrm{Mg}_{17} \mathrm{Al}_{12}$ fusion is attributed to the galvanic coupling between both compounds, which accelerates the corrosion of the anode ( $\mathrm{Mg}$ in this case). 
On the other hand, ball milling was reported as an efficient method to ameliorate the hydrolysis reactivity of Mg-based materials [50, 51]. In fact, ball milling improves the hydrolysis performance of $\mathrm{Mg}$ and $\mathrm{Mg}_{17} \mathrm{Al}_{12}$ without exceeding the hydrolysis performance of $\mathrm{Mg}+\mathrm{Mg}_{17} \mathrm{Al}_{12}$ milling (Figure 6.b). Once again, the better kinetics obtained with $\mathrm{Mg}+\mathrm{Mg}_{17} \mathrm{Al}_{12}$ milling is attributed to the galvanic coupling. This is attributed to the reduction of the particle size of $\mathrm{Mg}$ and $\mathrm{Mg}_{17} \mathrm{Al}_{12}$ (promotion of the surface distribution) which increases the contact between the anode and the cathode.

\subsection{Corrosion behavior}

Open Circuit Potential (OCP) for each material involved in this investigation was recorded during 30 minutes of immersion in $\mathrm{NaCl}$ solution. Table 2 shows the average OCP values calculated in when the corrosion of the material is in a full steady state (i.e. the potential was stable from 15 minutes to 30 minutes of immersion). It is important to point out the difference between two physical values that are very close but different in concept: the OCP and the corrosion potential $\mathrm{E}_{\text {corr. }}$ On the one hand, the OCP is the equilibrium potential between oxidation/reduction of a Mgbased material and it is measured when the material is immersed in electrolyte without applying any potential. On the other hand, the corrosion potential is obtained in similar conditions where cathodic and anodic reactions have the same intensity so that the current at $\mathrm{E}_{\text {corr }}$ is minimal [52]. In the present study, the OCP was estimated when the corrosion of the material is in fully steady state. Consequently, OCP is practically equal to $E_{\text {corr }}$ (Table 2 and Figure 7.a).

Table 2: OCP values and corrosion current density $\left(\mathrm{J}_{\text {corr }}\right)$ for all the materials involved in this study.

\begin{tabular}{|l|c|c|}
\hline \multicolumn{1}{|c|}{ Sample } & OCP $($ V/SCE) & Jcorr $\left(\mathbf{m A} / \mathbf{c m}^{2}\right)$ \\
\hline $\mathrm{Mg}-\mathrm{Al}-\mathrm{Zn}$ & $-1.63 \pm 0.05$ & $4.0 \pm 0.1$ \\
\hline $\mathrm{AZ91}$ powder & $-1.44 \pm 0.04$ & $0.35 \pm 0.02$ \\
\hline $\mathrm{AZ91}$ alloy & $-1.63 \pm 0.05$ & $0.03 \pm 0.001$ \\
\hline $\mathrm{Mg}+\mathrm{Mg}_{17} \mathrm{Al}_{12}$ fusion & $-1.62 \pm 0.05$ & $9.5 \pm 0.4$ \\
\hline $\mathrm{Mg}+\mathrm{Mg}_{17} \mathrm{Al}_{12}$ milling & $-1.61 \pm 0.05$ & $0.40 \pm 0.02$ \\
\hline
\end{tabular}


The OCP can be estimated following the rule of mixture [46] by taking into consideration the surface distribution and the $\mathrm{OCP}$ of $\mathrm{Mg}$ and $\mathrm{Mg}_{17} \mathrm{Al}_{12}$. The structural and morphological dissimilarities (i.e. the surface distribution of $\mathrm{Mg}$ and $\mathrm{Mg}_{17} \mathrm{Al}_{12}$ ) between $\mathrm{Mg}-\mathrm{Al}-\mathrm{Zn}, \mathrm{AZ91}$ alloy, $\mathrm{Mg}+\mathrm{Mg}_{17} \mathrm{Al}_{12}$ fusion and milling didn't affect their corrosion potential (i.e. $\mathrm{E}_{\text {corr }}$ of -1.6 V/SCE, $C f$ Table 2). AZ91 powder exhibits higher OCP value (e.g. -1.44 V/SCE); this increase is probably attributed to its smaller particles (implied $\mathrm{Mg}_{17} \mathrm{Al}_{12}, C f$ section 3.1) which increase the surface distribution of $\mathrm{Mg}_{17} \mathrm{Al}_{12}$ leading to higher OCP values.
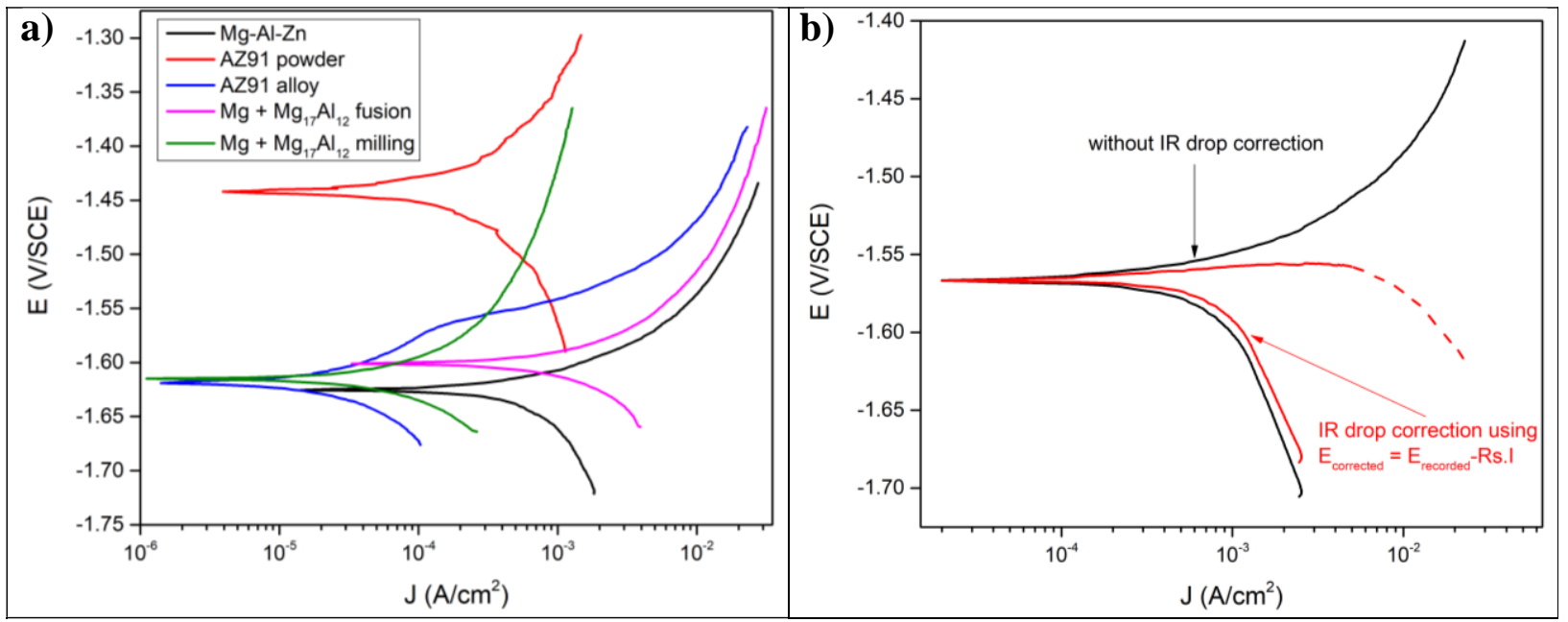

Figure 7: a) Anodic polarization curve for $\mathrm{Mg}-\mathrm{Al}-\mathrm{Zn}$, $\mathrm{AZ91}$ powder, $\mathrm{AZ91}$ alloy, $\mathrm{Mg}+\mathrm{Mg}_{17} \mathrm{Al}_{12}$ fusion and $\mathrm{Mg}+\mathrm{Mg}_{17} \mathrm{Al}_{12}$ milling and b) anodic polarization curve for $\mathrm{Mg}-\mathrm{Al}-\mathrm{Zn}$ obtained after IR drop correction using the relative and the absolute value of the measured current I.

During the polarization of $\mathrm{Mg}$-based materials (Figure 7.a), even with a minimal anodic polarization, a very high anodic current is observed, accompanied by an evolution of hydrogen and a local alkalization [53]. This phenomenon produces the ohmic drop (subsequently named IR drop) in proximity of the working electrode surface and can be corrected according to the equation:

$$
\mathrm{E}_{\text {corrected }}=\mathrm{E}_{\text {recorded }}-\text { Rs.I }
$$

where $\mathrm{E}_{\text {corrected }}$ and $\mathrm{E}_{\text {recorded }}$ are the applied potential before and after IR drop correction respectively, Rs is the solution resistance estimated from electrochemical impedance spectroscopy measurements and I is the measured current. 
Figure 7.b shows the influence of IR drop correction on the intensity-potential curve obtained for Mg-Al-Zn. The shape of the curves alteration after IR drop correction is attributed to the complicated nature of Mg alloys in anodic polarization state $[54,55]$ but essentially to the evolution of the solution resistance [53, 56]. In fact, Rs depends on the applied potential and is strongly affected by the generation of hydrogen bubbles and the local variation of the $\mathrm{pH}$ (formation of $\mathrm{Mg}(\mathrm{OH})_{2}$ ) [56]. Therefore and as recommended by Curioni [56], the anodic polarization results are not corrected for the IR drop. On the other hand, the fact that hydrogen generation is favored with increasing the applied potential during the anodic dissolution of $\mathrm{Mg}$ based materials (so that the anodic polarization is not only affect by the anodic reaction) questions the application of Tafel approximation for the estimation of long-term corrosion rates mainly for highly corroding materials $[55,57]$. However, we consider that this behavior occurs for all the materials involved in this study.

Corrosion current densities $\left(\mathrm{J}_{\text {corr }}\right)$ shown in Table 2 were estimated from the anodic polarization curves presented in Figure 7.a using the method described previously [58, 59]. During anodic corrosion, $\mathrm{Mg}-\mathrm{Al}-\mathrm{Zn}$ and the "model" materials do not reveal the presence of a passivation plateau as observed for the commercial AZ91 alloy (from $0 \mathrm{mV} / \mathrm{E}_{\text {corr }}$ to $50 \mathrm{mV} / \mathrm{E}_{\text {corr }}$ ). As expected, $\mathrm{Mg}$ Al-Zn powder corrodes faster than the commercial AZ91 alloy known as one of the best corrosion resistant Mg-based alloys ( $\mathrm{J}_{\text {corr }}=4 \mathrm{~mA} / \mathrm{cm}^{2}$ for Mg-Al-Zn vs. $\mathrm{J}_{\text {corr }}=0.03 \mathrm{~mA} / \mathrm{cm}^{2}, C f$ Table 2). The corrosion current density of $\mathrm{Mg}+\mathrm{Mg}_{17} \mathrm{Al}_{12}$ fusion is greater than that of $\mathrm{Mg}-\mathrm{Al}-\mathrm{Zn}$ powder $(4$ $\left.\mathrm{mA} / \mathrm{cm}^{2}\right)$ and AZ91 alloy $\left(0.03 \mathrm{~mA} / \mathrm{cm}^{2}\right)$ respectively, in total agreement with the results of the hydrolysis tests.

On the other hand, $\mathrm{Mg}+\mathrm{Mg}_{17} \mathrm{Al}_{12}$ fusion exhibits higher corrosion current densities than $\mathrm{Mg}+\mathrm{Mg}_{17} \mathrm{Al}_{12}$ milling and $\mathrm{AZ91}$ powder respectively (i.e. $0.4 \mathrm{~mA} / \mathrm{cm}^{2}$ and $0.35 \mathrm{~mA} / \mathrm{cm}^{2}$ for $\mathrm{Mg}+\mathrm{Mg}_{17} \mathrm{Al}_{12}$ milling and AZ91 powder respectively, $C f$ Table 2). The apparently conflicting results between hydrolysis and anodic polarization come from the fact that hydrolysis allows the study of the reactivity of the whole material while anodic polarization allows to estimate the reactivity of its surface. Therefore, these results are complementary and not contradictory. In fact, low $\mathrm{J}_{\text {corr }}$ indicates that the surface of the working electrode is less electrochemically reactive. This decrease is attributed to the formation of thick passivation layer on the surface due to the rapid corrosion during immersion in $\mathrm{NaCl}$ solution so that the surface is covered by an insulting material 
(considering that $\mathrm{AZ91}$ powder and $\mathrm{Mg}+\mathrm{Mg}_{17} \mathrm{Al}_{12}$ milling show the best hydrolysis performances, $C f$ Figure 5). As a consequence, whether the surface is totally or partially covered by the passivation layer, the active surface of $\mathrm{Mg}$ decreases which decreases the measured corrosion current, and consequently the corrosion current density drawn in Figure 7.a, which is defined by the ratio between the current and the sample surface. However, if this is the case, the resistance at the interface material-electrolyte should increase due to the presence of an "insulator" and the behavior of the system should be identical to that of a moderately or poorly conductive electrolyte [60]. Indeed, EIS measurements confirms that the solution resistances Rs (Table 3) are higher for the materials showing the highest hydrolysis performances and the lowest corrosion current densities (i.e. AZ91 powder and $\mathrm{Mg}+\mathrm{Mg}_{17} \mathrm{Al}_{12}$ milling). These findings justify that the passivation layer formed during the corrosion of highly reactive materials affects long-term corrosion rate estimation.

Electrochemical impedance data for all the materials were recorded at OCP after 30 minutes of immersion in $\mathrm{NaCl}$. The experimental data were fitted according to the electrical equivalent circuit adopted previously to explain the effect of ball milling on the corrosion behavior of AZ91 [7, 55]. The equivalent circuit is defined by Rs (CPE1//(R1(CPE2//R2))//(R3L)) where the parenthesis groups the components connected in series (e.g. (R3L)) and the parallel lines (//) represent the complonents connected in parallel (e.g. CPE2//R2). From this circuit, the following EIS parameters are determined: Rs is the solution resistance, $\mathrm{C} 1$ and $\mathrm{C} 2$ are the effective capacitances of CPE1 and CPE2 respectively, $\mathrm{R}_{\mathrm{t}}$ the charge transfer resistance and $\mathrm{R}_{\mathrm{p}}$ the polarization resistance $[7,55,61]$. The inductive loop (indicative of the presence of reaction intermediates such as $\mathrm{Mg}^{+}$ $[18,62-64]$ or $\mathrm{MgH}^{+}$[21]) contribution is expressed by the inductor (L) incorporated in the electrical equivalent circuit $[55,65]$. The Nyquist and Bode spectra of the 5 materials in the 3.5 wt.\% $\mathrm{NaCl}$ solution are depicted in Figure 8.a and Figure 8.b respectively. The experimental data are displayed as scatter plot while the EIS fitting results are represented as line plot. 


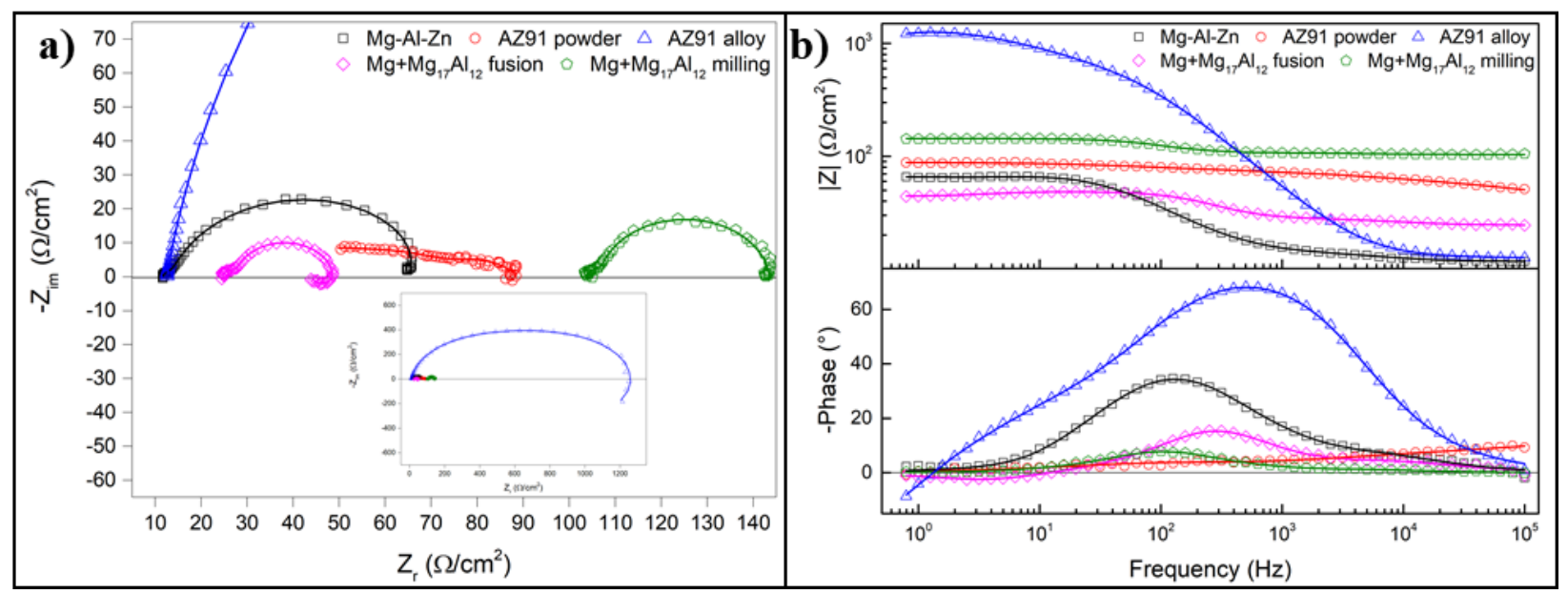

Figure 8: Nyquist (left) and bode (right) plots for Mg-Al-Zn, AZ91 powder, AZ91 alloy, $\mathrm{Mg}+\mathrm{Mg}_{17} \mathrm{Al}_{12}$ fusion and $\mathrm{Mg}+\mathrm{Mg}_{17} \mathrm{Al}_{12}$ milling. The inset in Figure 8.a presents the Nyquist plot of $\mathrm{AZ91}$ in $100 \mathrm{kHz}-$ $700 \mathrm{mHz}$ range.

The reference, the commercial alloy and the 3 models have different corrosion behaviors indicating the influence of $\mathrm{Mg}_{17} \mathrm{Al}_{12}$ on the corrosion behavior of $\mathrm{Mg}$-Al based materials. The double layer capacitance $\mathrm{C} 1[55,65,66]$ for AZ91 alloy is lower than that of $\mathrm{Mg}-\mathrm{Al}-\mathrm{Zn}, \mathrm{Mg}+\mathrm{Mg}_{17} \mathrm{Al}_{12}$ fusion and milling respectively (Table 3). As previously described [7], when corrosion rate increases, the working electrode surface becomes rougher (its surface area increases) and the double layer capacitance increases. For AZ91 powder, the surface impedance distribution (the order of the CPE1) is 0.46 indicating that this CPE1 has no significant physical meaning. It indicates that the corrosion is very fast and that the reaction mechanism is limited by the diffusion [20]. 
Table 3: Electrochemical parameters calculated from best fit of impedance data of Mg-Al-Zn, AZ91 powder, $\mathrm{AZ91}$ alloy, $\mathrm{Mg}+\mathrm{Mg}_{17} \mathrm{Al}_{12}$ fusion and $\mathrm{Mg}+\mathrm{Mg}_{17} \mathrm{Al}_{12}$ milling.

\begin{tabular}{|l|c|c|c|c|c|}
\hline & Mg-Al-Zn & AZ91 powder & AZ91 alloy & $\begin{array}{c}\text { Mg+Mg17Al } 12 \\
\text { fusion }\end{array}$ & $\begin{array}{c}\text { Mg+Mg17Al } \\
\text { milling }\end{array}$ \\
\hline $\mathbf{R}_{\mathbf{s}}\left(\mathbf{\Omega} / \mathbf{c m}^{\mathbf{2}}\right)$ & 12 & 32 & 13 & 25 & 104 \\
\hline $\mathbf{C}_{\mathbf{1}}\left(\boldsymbol{\mu} \mathbf{F} / \mathbf{c m}^{\mathbf{2}}\right)$ & 13 & $\mathrm{X}$ & 4.7 & 10 & 15 \\
\hline $\mathbf{C}_{\mathbf{2}}\left(\boldsymbol{\mu} \mathbf{F} / \mathbf{c m}^{\mathbf{2}}\right)$ & 63 & $\mathbf{3 3 2}$ & $\mathbf{9}$ & 51 & 72 \\
\hline $\mathbf{R}_{\mathbf{t}}\left(\mathbf{\Omega} / \mathbf{c m}^{\mathbf{2}}\right)$ & 54 & 57 & 1246 & 24 & 40 \\
\hline $\mathbf{R}_{\mathbf{p}}\left(\mathbf{\Omega} / \mathbf{c m}^{\mathbf{2}}\right)$ & $\mathbf{5 4}$ & $\mathbf{5 7}$ & $\mathbf{7 0 0}$ & $\mathbf{2 0}$ & $\mathbf{4 0}$ \\
\hline $\mathbf{R 3}\left(\mathbf{\Omega} / \mathbf{c m}^{2}\right)$ & 472 & 225 & 1372 & 105 & 655 \\
\hline $\mathbf{L}\left(\mathbf{H} / \mathbf{c m}^{\mathbf{2}}\right)$ & 9 & 0.001 & 842 & 5 & 0.002 \\
\hline
\end{tabular}

$\mathrm{X}$ : $\mathrm{C} 1$ value is negligible and it does not have a physical meaning since the surface impedance distribution is $0.46(\approx 0.5)$ [20].

C2 characterizes the adsorption pseudo capacitance of corrosion intermediate, corrosion product (i.e. $\left.\mathrm{Mg}(\mathrm{OH})_{2}\right)$ and/or cathodic reaction initiator sites [55, 67, 68]. Song et al. [68] showed that this capacitance increases when species, such as $\mathrm{Mg}(\mathrm{OH})_{2}$ are adsorbed on the surface. AZ91 shows the lowest $\mathrm{C} 2\left(9 \mu \mathrm{F} / \mathrm{cm}^{2}\right)$ indicating the lowest adsorption of the corrosion product $\mathrm{Mg}(\mathrm{OH})_{2}$. On the other side, AZ91 powder shows the highest $\mathrm{C} 2$ value of $332 \mu \mathrm{F} / \mathrm{cm}^{2}$.

The charge transfer resistance $R_{t}$ is determined from the EIS Nyquist plot where $Z_{i m} \rightarrow 0 \Omega / \mathrm{cm}^{2}$ (at $f>0 \mathrm{~Hz}$ ) and the polarization resistance $R_{p}$ is estimated for this equivalent circuit according to references [7, 55] (where $\mathrm{Z}_{\mathrm{im}} \rightarrow 0 \Omega / \mathrm{cm}^{2}$ at $\mathrm{f} \rightarrow 0 \mathrm{~Hz}$ ). Apart AZ91 alloy, $\mathrm{R}_{\mathrm{p}}$ and $\mathrm{R}_{\mathrm{t}}$ are the same for all the other materials due to the less significant contribution of the inductive loop. This suggests that, if a reaction intermediate (e.g. $\mathrm{Mg}^{+}$or $\mathrm{MgH}^{+}$) is formed, it is oxidized to form $\mathrm{Mg}^{2+}$ without adsorbing on the surface. $\mathrm{R}_{\mathrm{p}}$ is maximal for AZ91 alloy $\left(700 \Omega / \mathrm{cm}^{2}, C f\right.$ Table 3) due to the low corrosion rate for the reason that $\mathrm{R}_{\mathrm{p}}$ is inversely proportional to the surface area (while the surface area varies as the corrosion rate) [61]. Nevertheless, $\mathrm{Mg}+\mathrm{Mg}_{17} \mathrm{Al}_{12}$ fusion exhibits the lowest polarization resistance (i.e. $20 \Omega / \mathrm{cm}^{2}, C f$ Table 3) indicating the higher corrosion rate. The values of $R_{p}$ of $A Z 91$ powder and $\mathrm{Mg}+\mathrm{Mg}_{17} \mathrm{Al}_{12}$ milling $\left(57 \Omega / \mathrm{cm}^{2}\right.$ and $40 \Omega / \mathrm{cm}^{2}$ respectively) comparable to that of $\mathrm{Mg}-\mathrm{Al}-\mathrm{Zn}\left(54 \Omega / \mathrm{cm}^{2}\right)$ is attributed to the formation of a thick passivation layer which hinder the corrosion of the bulk material as previously clarified. 


\section{Conclusion}

In conclusion, we demonstrated how the manufacturing of $\mathrm{Mg}-\mathrm{Al}$ alloys (i.e. the distribution of $\mathrm{Mg}$ and $\mathrm{Mg}_{17} \mathrm{Al}_{12}$ ) affect the hardness, the hydrolysis performance and the corrosion behavior of the materials. The porous morphology of AZ91 powder proves the weak bond between Mg and $\mathrm{Mg}_{17} \mathrm{Al}_{12}$ and results from the leaving phase $\left(\mathrm{Mg}_{17} \mathrm{Al}_{12}\right)$.

The brittle characteristics of $\mathrm{Mg}_{17} \mathrm{Al}_{12}$ were demonstrated. The hardness of pure $\mathrm{Mg}_{17} \mathrm{Al}_{12}$ is 5 times higher than that of pure $\mathrm{Mg}\left(250 \mathrm{Hv}\right.$ vs. $45 \mathrm{Hv}$ ). As a consequence, when $\mathrm{Mg}_{17} \mathrm{Al}_{12}$ is used as ball mill additive (i.e. $\mathrm{Mg}+\mathrm{Mg}_{17} \mathrm{Al}_{12}$ milling), particle size is reduced and surface defects (e.g. cracks) are formed on $\mathrm{Mg}$ surface. On the other hand, the microhardness of $\mathrm{Mg}_{17} \mathrm{Al}_{12}$ is influenced by the presence of $\mathrm{Mg}$ due to composite effect. For instance, the hardness of $\mathrm{Mg}_{17} \mathrm{Al}_{12}$ increases gradually from $\mathrm{Mg}-\mathrm{Mg}_{17} \mathrm{Al}_{12}$ interface to the center of $\mathrm{Mg}_{17} \mathrm{Al}_{12}$ particle.

The comparison of the hydrolysis performance of (i) pure $\mathrm{Mg}$, pure $\mathrm{Mg}_{17} \mathrm{Al}_{12}$ and $\mathrm{Mg}+\mathrm{Mg}_{17} \mathrm{Al}_{12}$ fusion and (ii) milled $\mathrm{Mg}$, milled $\mathrm{Mg}_{17} \mathrm{Al}_{12}$ and $\mathrm{Mg}+\mathrm{Mg}_{17} \mathrm{Al}_{12}$ milling shows the beneficial effect of the galvanic coupling between $\mathrm{Mg}$ and $\mathrm{Mg}_{17} \mathrm{Al}_{12}$ on the hydrolysis performance of the powder. $\mathrm{Mg}+\mathrm{Mg}_{17} \mathrm{Al}_{12}$ milling presents the best hydrolysis performance with a yield of $80 \%$ of its theoretical hydrogen production capacity reached in 60 minutes of reaction with $3.5 \mathrm{wt} . \% \mathrm{NaCl}$ aqueous solution. This is probably attributed to the galvanic corrosion and the pitting corrosion favored by the presence of $\mathrm{Cl}^{-}$and surface defects in this latter model material. Based on electrochemical test results, the corrosion reactivity is maximal for $\mathrm{Mg}_{+} \mathrm{Mg}_{17} \mathrm{Al}_{12}$ fusion with the highest corrosion current density $\left(\mathrm{J}_{\text {corr }}=9.5 \mathrm{~mA} / \mathrm{cm}^{2}\right)$ and lowest polarization resistance $\left(\mathrm{R}_{\mathrm{p}}=20\right.$ $\left.\Omega / \mathrm{cm}^{2}\right)$ compared to Mg-Al-Zn $\left(\mathrm{J}_{\text {corr }}=4.0 \mathrm{~mA} / \mathrm{cm}^{2}\right.$ and $\left.\mathrm{R}_{\mathrm{p}}=54 \Omega / \mathrm{cm}^{2}\right)$ and AZ91 alloy $\left(\mathrm{J}_{\text {corr }}=\right.$ $0.03 \mathrm{~mA} / \mathrm{cm}^{2}$ and $\mathrm{R}_{\mathrm{p}}=700 \Omega / \mathrm{cm}^{2}$ ).

Hydrolysis and electrochemical tests are generally complementary to evaluate the hydrogen production (the same phenomenon as the anodic corrosion) from Mg-based materials except when the anodic corrosion is very fast. In this case, the thick passivation layer formed hinder the corrosion of the bulk material so that the behavior of the insulating passivation layer is exploited instead of the bulk material. 
Our results show that when the particle size of $\mathrm{Mg}+\mathrm{Mg}_{17} \mathrm{Al}_{12}$ is reduced, the galvanic coupling between $\mathrm{Mg}$ and $\mathrm{Mg}_{17} \mathrm{Al}_{12}$ is more expressed. It is then worth pointing out that increasing ball milling efficiency of AZ91 until reaching the same powder state as " $\mathrm{Mg}+\mathrm{Mg}_{17} \mathrm{Al}_{12}$ milling" will improve the hydrogen generation by the hydrolysis reaction. The complete hydrolysis with AZ91 can then be reached by ball milling with additives such aluminum chloride to dissolve the formed $\mathrm{Mg}(\mathrm{OH})_{2}$. Moreover, AZ91 alloy can be given a "second life" as ball milling additive due to the fact that it shows a higher microhardness than that of $\mathrm{Mg}$.

\section{Acknowledgments}

This work was financially supported by the AZM \& SAADE Association, the Lebanese University

and Bordeaux foundation. The authors gratefully acknowledge Lionel Teule-Gay for his technical support with Vickers microhardness measurements. 


\section{Highlights}

1. Galvanic coupling improves the hydrolysis (corrosion) of AZ alloys.

2. The weak bond between $\mathrm{Mg}$ and $\mathrm{Mg}_{17} \mathrm{Al}_{12}$ was indirectly proved by SEM observations

3. The hardness of $\mathrm{Mg}_{17} \mathrm{Al}_{12}$ decreases at the interface $\mathrm{Mg}-\mathrm{Mg}_{17} \mathrm{Al}_{12}$.

4. The thick passivation layer formed during the corrosion results in underestimating the corrosion rate by anodic polarization and EIS. 


\section{Bibliography}

1. Palit, S., Recent Advances in Corrosion Science: A Critical Overview and a Deep Comprehension, in Direct Synthesis of Metal Complexes, B. Kharisov, Editor. 2018, Elsevier. p. 379-411.

2. Hamdy Makhlouf, A.S., Chapter 15 - Intelligent Stannate-Based Coatings of Self-Healing Functionality for Magnesium Alloys, in Intelligent Coatings for Corrosion Control, A. Tiwari, J. Rawlins, and L.H. Hihara, Editors. 2015, Butterworth-Heinemann: Boston. p. $537-555$.

3. Popov, B.N., Chapter 6 - Galvanic Corrosion, in Corrosion Engineering, B.N. Popov, Editor. 2015, Elsevier: Amsterdam. p. 239-287.

4. Alasmar, E., I. Aubert, A. Durand, M. Nakhl, M. Zakhour, E. Gaudin, and J.L. Bobet, Hydrogen generation from MgNdNiMg15 composites by hydrolysis reaction. International Journal of Hydrogen Energy, 2019. 44(2): p. 523-530.

5. Zhao, Y.-C., M.-C. Zhao, R. Xu, L. Liu, J.-X. Tao, C. Gao, C. Shuai, and A. Atrens, Formation and characteristic corrosion behavior of alternately lamellar arranged $\alpha$ and $\beta$ in as-cast AZ91 Mg alloy. Journal of Alloys and Compounds, 2019. 770: p. 549-558.

6. Rocca, E., C. Juers, and J. Steinmetz, Corrosion behaviour of chemical conversion treatments on as-cast $M g-A l$ alloys: Electrochemical and non-electrochemical methods. Corrosion Science, 2010. 52(6): p. 2172-2178.

7. Al Bacha, S., I. Aubert, M. Zakhour, M. Nakhl, and J.L. Bobet, Hydrogen production by the hydrolysis of ball milled AZ91 (Electrochemical approach). Submitted to Journal of Power Sources, 2020.

8. Dargusch, M.S., M. Nave, S.D. McDonald, and D.H. StJohn, The effect of aluminium content on the eutectic morphology of high pressure die cast magnesium-aluminium alloys. Journal of Alloys and Compounds, 2010. 492(1): p. L64-L68.

9. Song, G., A. Atrens, X. Wu, and B. Zhang, Corrosion behaviour of AZ21, AZ501 and AZ91 in sodium chloride. Corrosion Science, 1998. 40(10): p. 1769-1791.

10. Song, G., A. Atrens, and M. Dargusch, Influence of microstructure on the corrosion of diecast AZ91D. Corrosion Science, 1998. 41(2): p. 249-273.

11. Lunder, O., J.E. Lein, T.K. Aune, and K. Nisancioglu, The Role of Mg17Al12 Phase in the Corrosion of Mg Alloy AZ91. CORROSION, 1989. 45(9): p. 741-748.

12. Singh, I.B., M. Singh, and S. Das, A comparative corrosion behavior of Mg, AZ31 and AZ91 alloys in 3.5\% NaCl solution. Journal of Magnesium and Alloys, 2015. 3(2): p. 142148. 
13. Bland, L.G., L.C. Scully, and J.R. Scully, Assessing the Corrosion of Multi-Phase Mg-Al Alloys with High Al Content by Electrochemical Impedance, Mass Loss, Hydrogen Collection, and Inductively Coupled Plasma Optical Emission Spectrometry Solution Analysis. CORROSION, 2017. 73(5): p. 526-543.

14. Feng, H., S. Liu, Y. Du, T. Lei, R. Zeng, and T. Yuan, Effect of the second phases on corrosion behavior of the Mg-Al-Zn alloys. Journal of Alloys and Compounds, 2017. 695: p. $2330-2338$.

15. Wen, Z., C. Wu, C. Dai, and F. Yang, Corrosion behaviors of Mg and its alloys with different Al contents in a modified simulated body fluid. Journal of Alloys and Compounds, 2009. 488(1): p. 392-399.

16. Chen, J., J. Wang, E. Han, J. Dong, and W. Ke, States and transport of hydrogen in the corrosion process of an AZ91 magnesium alloy in aqueous solution. Corrosion Science, 2008. 50(5): p. 1292-1305.

17. Woo, S.K., C. Blawert, K.A. Yasakau, S. Yi, N. Scharnagl, B.-C. Suh, Y.M. Kim, B. Sun You, and C. Dong Yim, Effects of combined addition of $\mathrm{Ca}$ and $\mathrm{Y}$ on the corrosion behaviours of die-cast AZ91D magnesium alloy. Corrosion Science, 2020. 166: p. 108451.

18. Esmaily, M., J.E. Svensson, S. Fajardo, N. Birbilis, G.S. Frankel, S. Virtanen, R. Arrabal, S. Thomas, and L.G. Johansson, Fundamentals and advances in magnesium alloy corrosion. Progress in Materials Science, 2017. 89: p. 92-193.

19. Zhang, Z., G. Wu, A. Atrens, and W. Ding, Influence of trace As content on the microstructure and corrosion behavior of the AZ91 alloy in different metallurgical conditions. Journal of Magnesium and Alloys, 2020.

20. Al Bacha, S., I. Aubert, O. Devos, M. Zakhour, M. Nakhl, and J.L. Bobet, Corrosion behavior of pure Mg17Al12 and effect of ball milling in presence of additives (Graphite and $\mathrm{MgCl2}$ ). International Journal of Hydrogen Energy, 2020. 45(32): p. 15805-15813.

21. Al Bacha, S., A. Desmedt, and J.L. Bobet, Experimental evidence of $\mathrm{H}_{2}$ spillover during the corrosion of $\mathrm{Mg}_{17} \mathrm{Al} \mathrm{l}_{12}$. Submitted to Corrosion Science, 2020.

22. Zhao, M.-C., M. Liu, G. Song, and A. Atrens, Influence of the $\beta$-phase morphology on the corrosion of the Mg alloy AZ91. Corrosion Science, 2008. 50(7): p. 1939-1953.

23. Zhao, M.C., M. Liu, G.L. Song, and A. Atrens, Influence of Homogenization Annealing of AZ91 on Mechanical Properties and Corrosion Behavior. Advanced Engineering Materials, 2008. 10(1 - 2): p. 93-103.

24. Cheng, Y.-1., T.-w. Qin, H.-m. Wang, and Z. Zhang, Comparison of corrosion behaviors of AZ31, AZ91, AM60 and ZK60 magnesium alloys. Transactions of Nonferrous Metals Society of China, 2009. 19(3): p. 517-524. 
25. Zhao, M.C., P.J. Uggowitzer, M. Liu, P. Schmutz, G. Song, and A. Atrens, Corrosion of AZ91 - Influence of the $\beta$-Phase Morphology. Materials Science Forum, 2009. 618-619: p. 473-478.

26. Bütev Öcal, E., Z. Esen, K. Aydınol, and A.F. Dericioğlu, Comparison of the short and long-term degradation behaviors of as-cast pure Mg, AZ91 and WE43 alloys. Materials Chemistry and Physics, 2020. 241: p. 122350.

27. Al Bacha, S., M. Zakhour, M. Nakhl, and J.L. Bobet, Effect of ball milling in presence of additives (Graphite, $\mathrm{AlCl}_{3}, \mathrm{MgCl}_{2}$ and $\mathrm{NaCl}$ ) on the hydrolysis performances of $\mathrm{Mg}_{17} \mathrm{Al}_{12}$. International Journal of Hydrogen Energy, 2020. 45(11): p. 6102-6109.

28. Al Bacha, S., A.S. Awad, E. El Asmar, T. Tayeh, J.L. Bobet, M. Nakhl, and M. Zakhour, Hydrogen generation via hydrolysis of ball milled WE43 magnesium waste. International Journal of Hydrogen Energy, 2019. 44(33): p. 17515-17524.

29. Alasmar, E., A.S. Awad, D. Hachem, T. Tayeh, M. Nakhl, M. Zakhour, E. Gaudin, and J.L. Bobet, Hydrogen generation from $\mathrm{Nd}-\mathrm{Ni}-\mathrm{Mg}$ system by hydrolysis reaction. Journal of Alloys and Compounds, 2018. 740: p. 52-60.

30. Awad, A.S., E. El-Asmar, T. Tayeh, F. Mauvy, M. Nakhl, M. Zakhour, and J.L. Bobet, Effect of carbons ( $\mathrm{G}$ and $\mathrm{CFS}$ ), TM (Ni, Fe and Al) and oxides (Nb2O5 and V2O5) on hydrogen generation from ball milled Mg-based hydrolysis reaction for fuel cell. Energy, 2016. 95: p. 175-186.

31. Zhang, W., Q. Liu, Y. Chen, and G. Wan, Anodic dissolution dictates the negative difference effect (NDE) of magnesium corrosion more in chemical pathway. Materials Letters, 2018. 232: p. 54-57.

32. Thomaz, T.R., C.R. Weber, T. Pelegrini, L.F.P. Dick, and G. Knörnschild, The negative difference effect of magnesium and of the AZ91 alloy in chloride and stannate-containing solutions. Corrosion Science, 2010. 52(7): p. 2235-2243.

33. S. Al Bacha, P.S.A., Urretavizcaya, G., M. Zakhour, F.J. Castro, M. Nakhl, J.-L. Bobet, Effect of ball milling strategy on the hydrolysis performance of Mg alloy waste. Accepted in the International Journal of Hydrogen Energy, 2020.

34. S. Al Bacha, P.S.A., Urretavizcaya, G., M. Zakhour, F.J. Castro, M. Nakhl, J.-L. Bobet, Hydrogen generation from ball milled Mg alloy waste by hydrolysis reaction. Submitted to Journal of Power Sources, 2020.

35. Uan, J.-Y., M.-C. Lin, C.-Y. Cho, K.-T. Liu, and H.-I. Lin, Producing hydrogen in an aqueous $\mathrm{NaCl}$ solution by the hydrolysis of metallic couples of low-grade magnesium scrap and noble metal net. International Journal of Hydrogen Energy, 2009. 34(4): p. 1677-1687.

36. Uan, J.-Y., S.-H. Yu, M.-C. Lin, L.-F. Chen, and H.-I. Lin, Evolution of hydrogen from magnesium alloy scraps in citric acid-added seawater without catalyst. International Journal of Hydrogen Energy, 2009. 34(15): p. 6137-6142. 
37. Sunil, B.R., K.V. Ganesh, P. Pavan, G. Vadapalli, C. Swarnalatha, P. Swapna, P. Bindukumar, and G. Pradeep Kumar Reddy, Effect of aluminum content on machining characteristics of AZ31 and AZ91 magnesium alloys during drilling. Journal of Magnesium and Alloys, 2016. 4(1): p. 15-21.

38. V, S.C., R. Dumpala, A.K. S, K. Vv, and R.S. B, Influence of heat treatment on the machinability and corrosion behavior of AZ91 Mg alloy. Journal of Magnesium and Alloys, 2018. 6(1): p. 52-58.

39. Xu, S.W., N. Matsumoto, S. Kamado, T. Honma, and Y. Kojima, Effect of Mg17Al12 precipitates on the microstructural changes and mechanical properties of hot compressed AZ91 magnesium alloy. Materials Science and Engineering: A, 2009. 523(1): p. 47-52.

40. Lee, J.U., S.-H. Kim, Y.J. Kim, and S.H. Park, Effects of homogenization time on aging behavior and mechanical properties of AZ91 alloy. Materials Science and Engineering: A, 2018. 714: p. 49-58.

41. Chapter 6 - Evaluation methods for properties of nanostructured body, in Nanoparticle Technology Handbook (Second Edition), M. Hosokawa, et al., Editors. 2012, Elsevier: Amsterdam. p. 317-383.

42. Tayeh, T., A.S. Awad, M. Nakhl, M. Zakhour, J.F. Silvain, and J.L. Bobet, Production of hydrogen from magnesium hydrides hydrolysis. International Journal of Hydrogen Energy, 2014. 39(7): p. 3109-3117.

43. Xiao, F., Y. Guo, R. Yang, and J. Li, Hydrogen generation from hydrolysis of activated magnesium/low-melting-point metals alloys. International Journal of Hydrogen Energy, 2019. 44(3): p. 1366-1373.

44. Tolouie, E. and R. Jamaati, Effect of $\beta-M g 17 A l 12$ phase on microstructure, texture and mechanical properties of AZ91 alloy processed by asymmetric hot rolling. Materials Science and Engineering: A, 2018. 738: p. 81-89.

45. Monas, A., O. Shchyglo, S.-J. Kim, C.D. Yim, D. Höche, and I. Steinbach, Divorced Eutectic Solidification of Mg-Al Alloys. JOM, 2015. 67(8): p. 1805-1811.

46. Alasmar, E., Systèmes ternaires à base de magnésium : synthèse, structure, propriétés physiques, stockage et/ou production d'hydrogène. 2018.

47. Revie, R.W., Uhlig's corrosion handbook. Vol. 51. 2011: John Wiley \& Sons.

48. Grosjean, M.H., M. Zidoune, and L. Roué, Hydrogen production from highly corroding Mg-based materials elaborated by ball milling. Journal of Alloys and Compounds, 2005. 404-406: p. 712-715.

49. Hattori, Y., Y. Haruna, and M. Otsuka, Dissolution process analysis using model-free Noyes-Whitney integral equation. Colloids and Surfaces B: Biointerfaces, 2013. 102: p. 227-231. 
50. Grosjean, M.-H., M. Zidoune, L. Roué, J. Huot, and R. Schulz, Effect of ball milling on the corrosion resistance of magnesium in aqueous media. Electrochimica Acta, 2004. 49(15): p. 2461-2470.

51. Xie, X., C. Ni, B. Wang, Y. Zhang, X. Zhao, L. Liu, B. Wang, and W. Du, Recent advances in hydrogen generation process via hydrolysis of Mg-based materials: A short review. Journal of Alloys and Compounds, 2020. 816: p. 152634.

52. Zhang, X.G., Corrosion Potential and Corrosion Current, in Corrosion and Electrochemistry of Zinc. 1996, Springer US: Boston, MA. p. 125-156.

53. Curioni, M., F. Scenini, T. Monetta, and F. Bellucci, Correlation between electrochemical impedance measurements and corrosion rate of magnesium investigated by real-time hydrogen measurement and optical imaging. Electrochimica Acta, 2015. 166: p. 372-384.

54. Cui, Z., F. Ge, Y. Lin, L. Wang, L. Lei, H. Tian, M. Yu, and X. Wang, Corrosion behavior of AZ31 magnesium alloy in the chloride solution containing ammonium nitrate. Electrochimica Acta, 2018. 278: p. 421-437.

55. King, A.D., N. Birbilis, and J.R. Scully, Accurate Electrochemical Measurement of Magnesium Corrosion Rates; a Combined Impedance, Mass-Loss and Hydrogen Collection Study. Electrochimica Acta, 2014. 121: p. 394-406.

56. Curioni, M., The behaviour of magnesium during free corrosion and potentiodynamic polarization investigated by real-time hydrogen measurement and optical imaging. Electrochimica Acta, 2014. 120: p. 284-292.

57. Shi, Z., M. Liu, and A. Atrens, Measurement of the corrosion rate of magnesium alloys using Tafel extrapolation. Corrosion Science, 2010. 52(2): p. 579-588.

58. Jayaraj, J., S. Amruth Raj, A. Srinivasan, S. Ananthakumar, U.T.S. Pillai, N.G.K. Dhaipule, and U.K. Mudali, Composite magnesium phosphate coatings for improved corrosion resistance of magnesium AZ31 alloy. Corrosion Science, 2016. 113: p. 104-115.

59. Zheng, T., Y. Hu, F. Pan, Y. Zhang, and A. Tang, Fabrication of corrosion-resistant superhydrophobic coating on magnesium alloy by one-step electrodeposition method. Journal of Magnesium and Alloys, 2019. 7(2): p. 193-202.

60. Chechirlian, S., Contribution à l'étude électrochimique de la corrosion dans les milieux a faible conductivité : application à l'étude du comportement d'aciers inoxydables austénitiques dans les solutions concentrées d'acide acétique. 1989. p. 1 vol. (218p.).

61. Córdoba-Torres, P., Relationship between constant-phase element (CPE) parameters and physical properties of films with a distributed resistivity. Electrochimica Acta, 2017. 225 : p. 592-604.

62. Klotz, D., Negative capacitance or inductive loop? - A general assessment of a common low frequency impedance feature. Electrochemistry Communications, 2019. 98: p. 58-62. 
63. Dobbelaar, J.A.L. and J.H.W. de Wit, Impedance Measurements and Analysis of the Corrosion of Chromium. Journal of The Electrochemical Society, 1990. 137(7): p. 20382046.

64. Bender, S., J. Goellner, A. Heyn, and S. Schmigalla, A new theory for the negative difference effect in magnesium corrosion. Materials and Corrosion, 2012. 63(8): p. 707712.

65. Orazem, M.E. and B. Tribollet, Electrochemical impedance spectroscopy. 2017: John Wiley \& Sons.

66. Agarwal, P., Measurement Models for Electrochemical Impedance Spectroscopy. Journal of The Electrochemical Society, 1992. 139(7): p. 1917.

67. Murray, J.N., P.J. Moran, and E. Gileadi, Utilization of the Specific Pseudocapacitance for Determination of the Area of Corroding Steel Surfaces. CORROSION, 1988. 44(8): p. 533538.

68. Song, G. and D. StJohn, Corrosion behaviour of magnesium in ethylene glycol. Corrosion Science, 2004. 46(6): p. 1381-1399. 